NBS MONOGRAPH 5

\title{
Preservation of Documents by Lamination
}

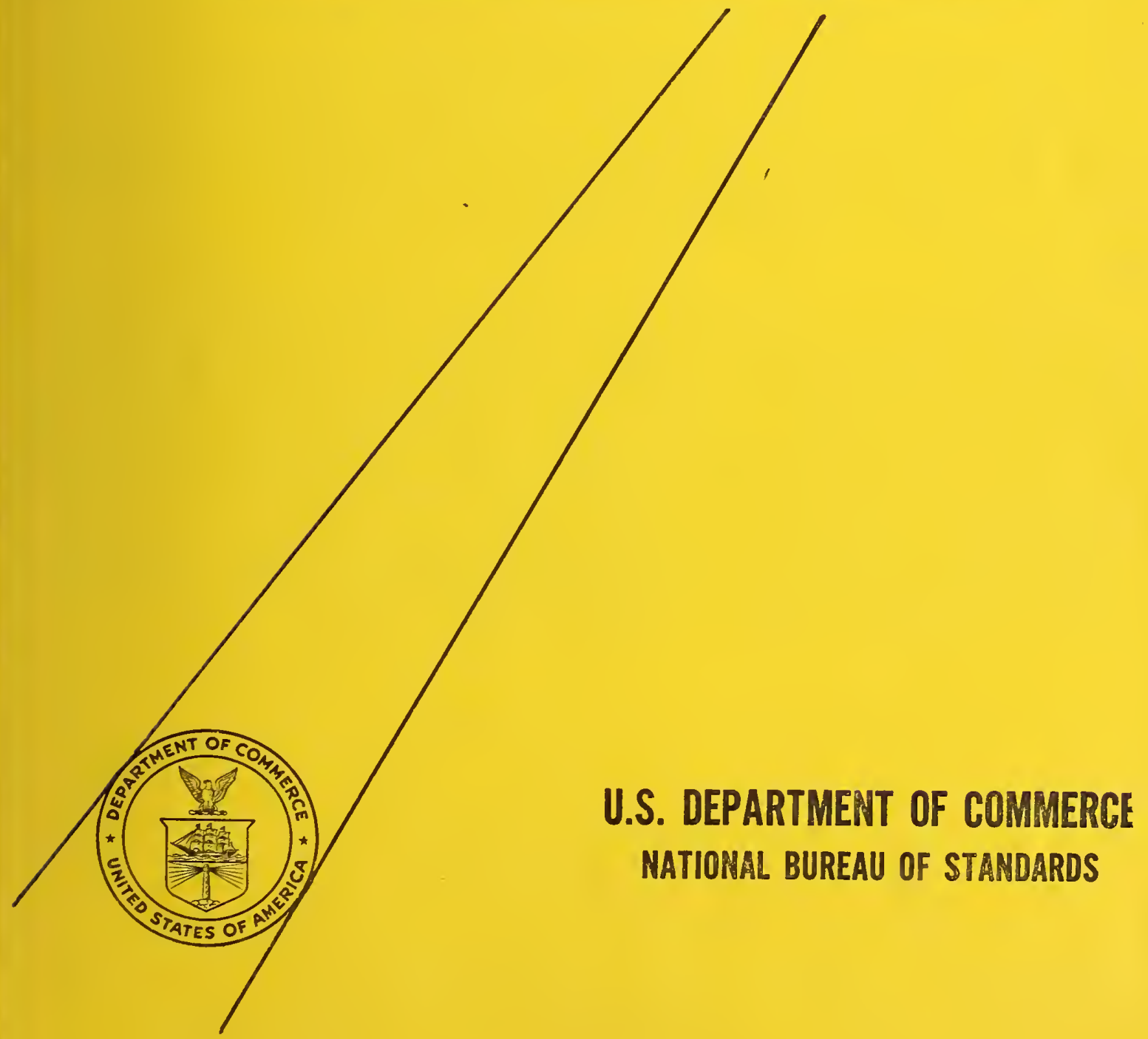




\section{THE NATIONAL BUREAU OF STANDARDS}

\section{Functions and Activities}

The functions of the National Bureau of Standards are set forth in the Act of Congress, March 3, 1901, as amended by Congress in Public Law 619, 1950. These include the development and maintenance of the national standards of measurement and the provision of means and methods for making measurements consistent with these standards; the determination of physical constants and properties of materials; the development of methods and instruments for testing materials, devices, and structures; advisory services to government agencies on scientific and technical problems; invention and development of devices to serve special needs of the Government; and the development of standard practices, codes, and specifications. The work includes basic and applied research, development, engineering, instrumentation, testing, evaluation, calibration services, and various consultation and information services. Research projects are also performed for other government agencies when the work relates to and supplements the basic program of the Bureau or when the Bureau's unique competence is required. The scope of activities is suggested by the listing of divisions and sections on the inside of the back cover.

\section{Publications}

The results of the Bureau's work take the form of either actual equipment and devices or published papers. These papers appear either in the Bureau's own series of publications or in the journals of professional and scientific societies. The Bureau itself publishes three periodicals available from the Government Printing Office: The Journal of Research, published in four separate sections, presents complete scientific and technical papers; the Technical News Bulletin presents summary and pre. liminary reports on work in progress; and Basic Radio Propagation Predictions provides data for determining the best frequencies to use for radio communications throughout the world. There are also five series of nonperiodical publications: Monographs, Applied Mathematics Series, Handbooks, Miscellaneous Publications, and Technical Notes.

Information on the Bureau's publications can be found in NBS Circular 460, Publications of the National Bureau of Standards $(\$ 1.25)$ and its Supplement (\$1.50), available from the Superintendent of Documents, Government Printing Office, Washington 25, D.C. 
UNITED STATES DEPARTMENT OF COMMERCE • Frederick H. Mueller, Secretary NATIONAL BUREAU OF STANDARDS - A. V. Astin, Director

\title{
Preservation of Documents by Lamination
}

\author{
William K. Wilson and B. W. Forshee
}

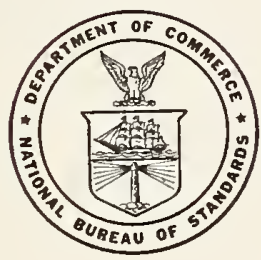

National Bureau of Standards Monograph 5

Issued October 30, 1959 



\section{Contents}

1. Introduction.

2. Properties of an ideal laminating film

3. Properties of cellulose acetate laminating film

3.1. Stability of cellulose acetate films

3.2. Plasticizer loss of cellulose acetate films

a. General__.

b. Materials and methods of test

c. Results and discussion

3.3. Physical properties of cellulose acetate films

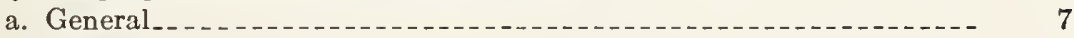

b. Materials and methods of test._.

c. Results and discussion

4. Degradation of film and papèr during lamination

5. Tissue reinforcement._. 12

6. Deacidification

7. Special laminating methods

8. Preliminary study of films other than cellulose acetate

9. Specifications for archival laminating film formulated from cellulose acetate_-_-- 17

9.1. General _.

9.2. Test methods

9.3. Improvements in specifications

9.4. Problems in procurement. 19

10. References. 



\title{
Preservation of Documents by Lamination
}

\author{
William K. Wilson and B. W. Forshee
}

\begin{abstract}
The chemical stability and physical properties of cellulose acetate film used to preserve and restore old or damaged documents by lamination were investigated. Pretreatment of documents with alkaline media before lamination is desirable if the paper contains an appreciable amount of acid. The lamination process does not degrade cellulose acetate film to a measurable extent. Acid-free papers are not degraded during lamination, but papers containing acid are degraded in proportion to the amount of acid present. Tissue added to the laminate increases the tensile strength and internal tear resistance, but decreases edge-tear resistance as compared to that of film alone extending beyond the paper.

The loss of plasticizer with time from a cellulose acetate laminating film does not impair the properties of the laminate. Composition and performance specifications for a cellulose acetate laminating film suitable for archival use are presented. The properties of polyethylene and polyethylene terephthalate films of interest in connection with their possible use for the protection of documents are discussed.
\end{abstract}

\section{Introduction}

The lamination of documents with cellulose acetate film as a means of preservation and restoration has been practiced for morè than 20 years [1]. ${ }^{1} \quad$ The National Bureau of Standards was asked by the National Archives, Army Map Service, Library of Congress, and Virginia State Library to investigate several aspects of the preservation of documents by lamination. The principal objective of this program, which was supported by these agencies, was to develop information necessary to establish specifications for cellulose acetate film of commercially practicable quality that would have the maximum stability for lamination.

\section{Properties of an Ideal Laminating Film}

An ideal laminating film could be described as having the following properties:

(1) It should be very flexible, and able to withstand all of the flexing or folding that is required of a paper during use.

(2) It should be considerably stronger than the paper it protects. Most papers that might be found in repositories exhibit an elongation of about 2 percent upon rupture. Therefore, in order to protect the body of the document, the film should show satisfactory strength at an elongation of less than 2 percent. As a practical consideration, the film should be strong enough to make reinforcement with tissue unnecessary and, if possible, to eliminate the use of cloth on maps as a part of such laminates.

(3) It should have considerable elongation beyond the yield point on a stress-strain curve, as a high edge tear is usually associated with high elongation. By leaving a narrow margin of film around the edges of the laminate, a strain at the edge would result in elongation of the film,

1 Figures in brackets indieate the literature references at the end of this monograph. but not in damage to the paper.

(4) It should be resistant to abrasion.

(5) It should be resistant to degradation. The film should be inherently stable and resistant to any environmental conditions that it could reasonably be expected to encounter.

(6) It should be possible to attach the film to the paper with a minimum of effort, preferably at room temperature, either in a small shop without special equipment or in a large shop using machines for greater production.

(7) It should be possible to remove the film from the paper, if this should become necessary, with a minimum of effort and without damage to the paper.

(8) The film should be transparent to light throughout the visible spectrum and preferably in to the infrared and ultraviolet.

At present there is no known film that complotely meets all these requirements, although a properly formulated cellulose acetate film represents a good compromise. Resistance to abrasion and transmission of light were not included in the work reported in this paper. 


\section{Properties of Cellulose Acetate Laminating Film}

\subsection{Stability of Cellulose Acetate Films}

The work on the degradation of cellulose acetate film conducted in the course of this investigation has been published elsewhere [2], and only a summary of the most important findings will be given here. Several commercial films and laboratory films were degraded at elevated temperatures in oxygen or nitrogen, and the reaction was followed by determining the intrinsic viscosity of specimens at intervals. Intrinsic fluidity was calculated from intrinsic viscosity, and the slope of the plot of intrinsic fluidity against time was taken as one criterion of degradation. The numerical value of intrinsic fluidity increases with degradation.

Two cellulose acetate films were selected for intensive study - a plasticized film and an experimental unplasticized film. The change in intrinsic fluidity of the plasticized film with time was studied at temperatures ranging from $60^{\circ}$ to $177^{\circ} \mathrm{C}$, and the unplasticized film was studied at temperatures ranging from $110^{\circ}$ to $176^{\circ} \mathrm{C}$. Degradation was principally oxidative in nature, and moisture did not appreciably affect the degradation under the experimental conditions that were used.

Typical plots for the degradation of a cellulose acetate film in moist and dry oxygen are given in figure 1. A slow initial reaction is followed by a

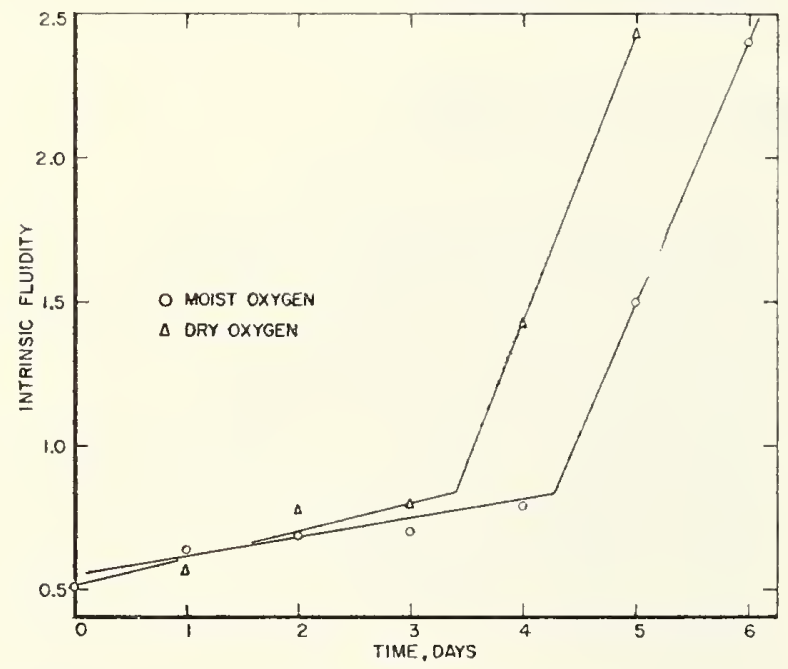

FIgURE 1. Degradation of commercial cellulose acetate film No. 4 (1-mil thick) in moist and dry oxygen at $110^{\circ} \mathrm{C}$.

very fast secondary reaction. The slow reaction is the more important in the study of films for archival use, as a film has usually lost most of its usefulness at the end of the slow reaction period.

Considerable information can be obtained by plotting the logarithm of the degradation rate against the reciprocal of the absolute temperature. Such a plot is shown in figure 2 for the initial degradation of these two films in dry oxygen at various temperatures; the change in intrinsic fluidity $(\Delta F)$ per hour is plotted against the reciprocal of the absolute temperature. The straight lines indicate that the same reaction is occurring at each temperature but at a different rate. The slope of the line is a measure of the energy required to activate the reaction. It is obvious that the unplasticized film is the more stable of the two films.

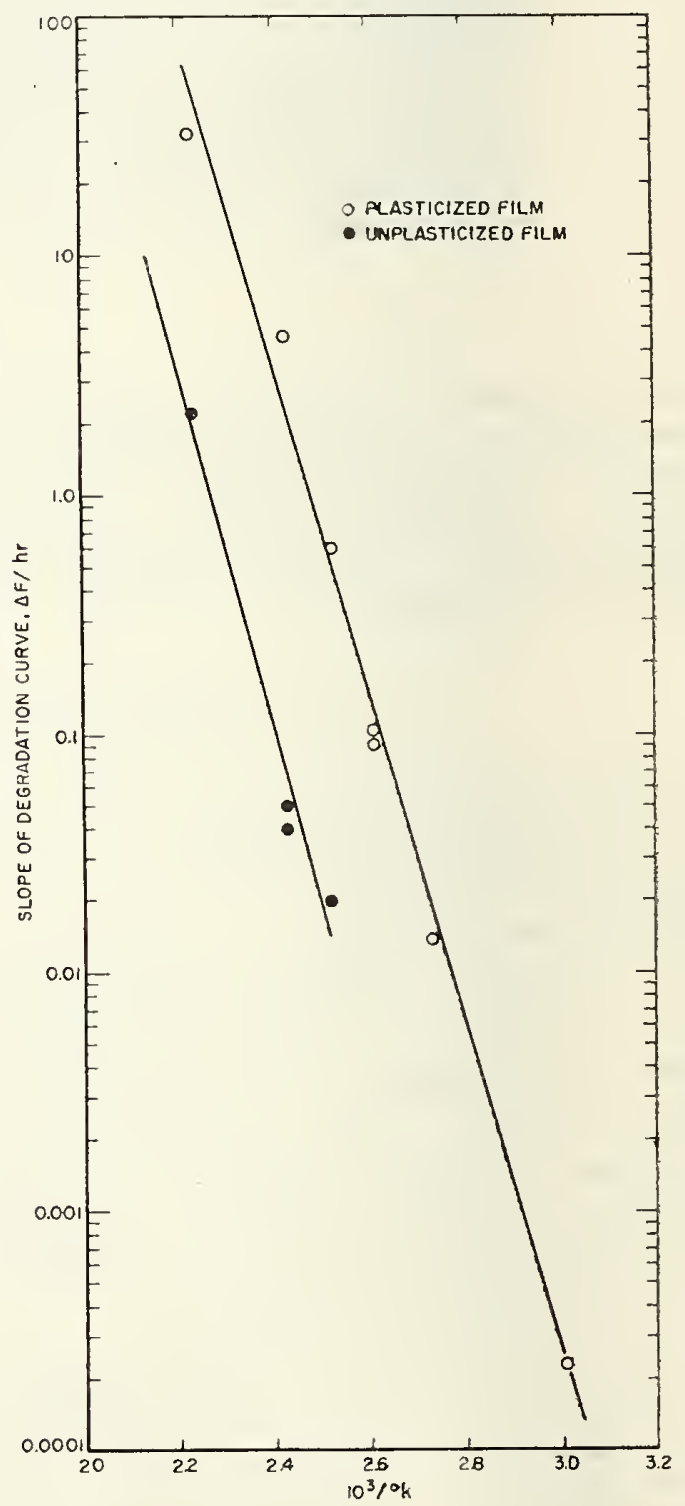

Figdre 2. Arrhenius plots for the initial degradation reaction of two cellulose acetate films. 
On the basis of the data obtained on these two films over a wide temperature range, a single temperature was selected at which to study the degradation rate of other commercial and experimental films. The change in intrinsic fluidity of these films with time was determined after aging at $124^{\circ} \mathrm{C}$ in flowing oxygen moistened with water vapor at $30^{\circ} \mathrm{C}$. Less stable films are degraded in one or two days at this temperature while more stable films may last two or three months. The selection of the concentration of water vapor was arbitrary, as water vapor did not appear to have any great influence on the rate of degradation.

Data on the degradation of 11 commercial cellulose acetate films in moist oxygen at $124^{\circ} \mathrm{C}$ are plotted in figures 3,4 , and 5 . Films numbers

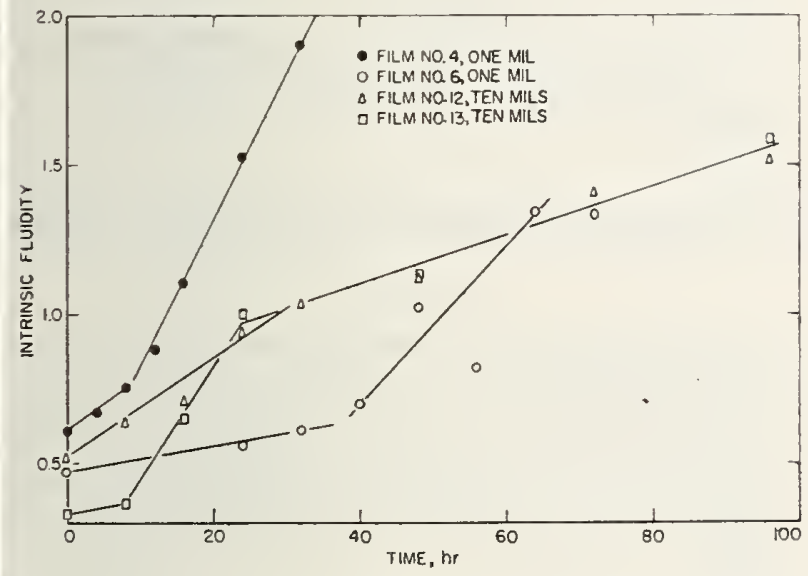

FIgURE 3. Degradation of commercial cellulose acetote films in moist oxygen at $124^{\circ} \mathrm{C}$.

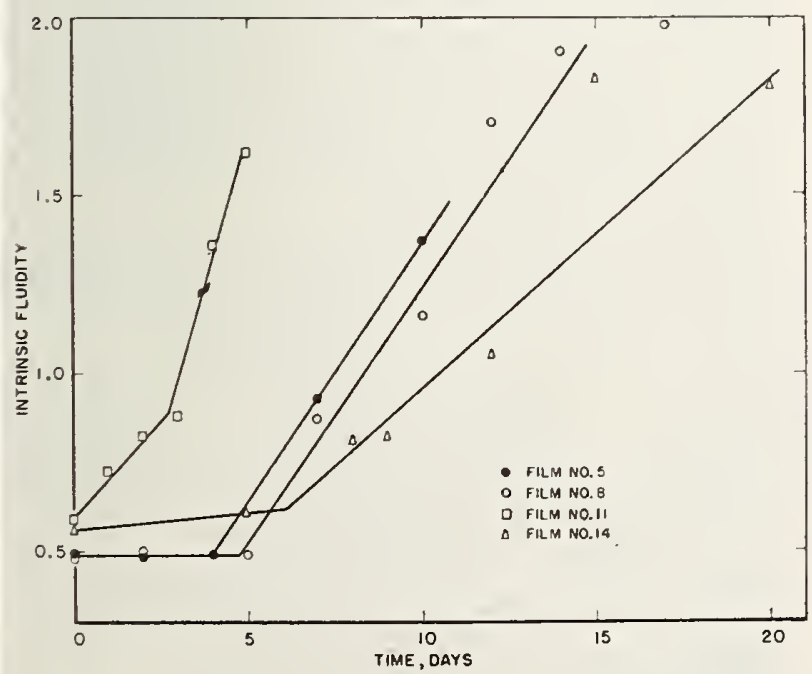

Figure 4. Degradation of commercial cellulose acetate films (1-mil thick) in morst oxygen at $124^{\circ} \mathrm{C}$.

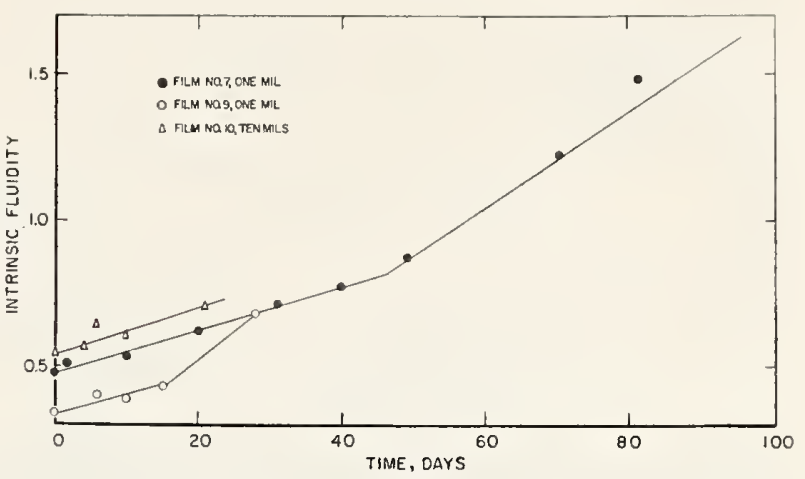

Figure 5. Degradation of commercial cellulose acelote films in moist oxygen at $124^{\circ} \mathrm{C}$.

10 and 14 are extruded films, while the remainder are cast films. These films show very great differences in rate of degradation. Numbers 9 and 10 were not aged long enough to determine the shape of the aging curve. The remainder of the films, with the exception of numbers 12 and 13 , show the typical initial slow reaction or initiation period followed by a more rapid degradation. A rapid initial reaction followed by a slower reaction is exhibited by numbers 12 and 13 .

The degradation rates of several experimental cellulose acetate films are shown in figures 6,7 , and 8 as part of a study of the effect of typical plasticizers on stability. Each plasticized film contains 20-percent plasticizer, based on the weight of the film. It is obvious that plasticizers can greatly influence the stability of cellulose acetate. In agreement with published data [3], triphenyl phosphate acts as a stabilizer. As shown in figure 8, ether esters can cause serious degradation.

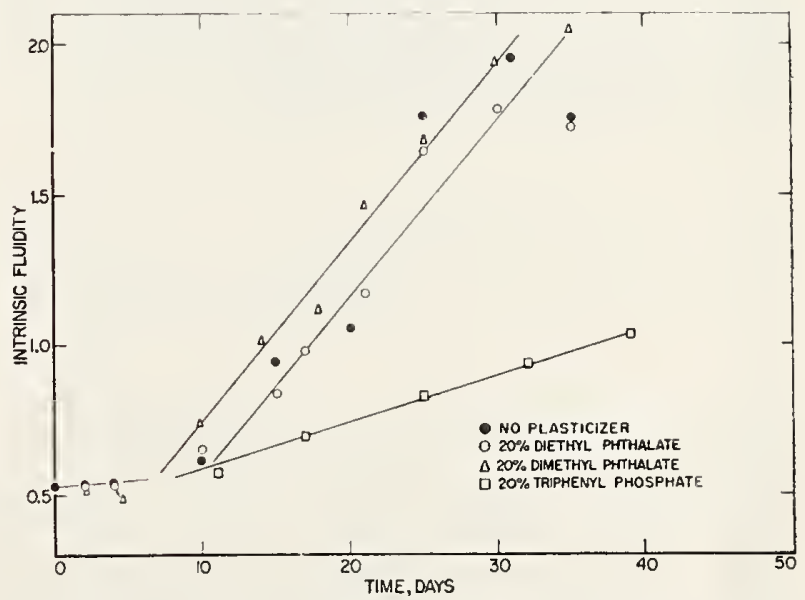

Figure 6. Degradation of experimental cellulose acetate films (1-mil thick) in moist oxygen at $124^{\circ} \mathrm{C}$; flake $\boldsymbol{A}$ with various plasticizers. 


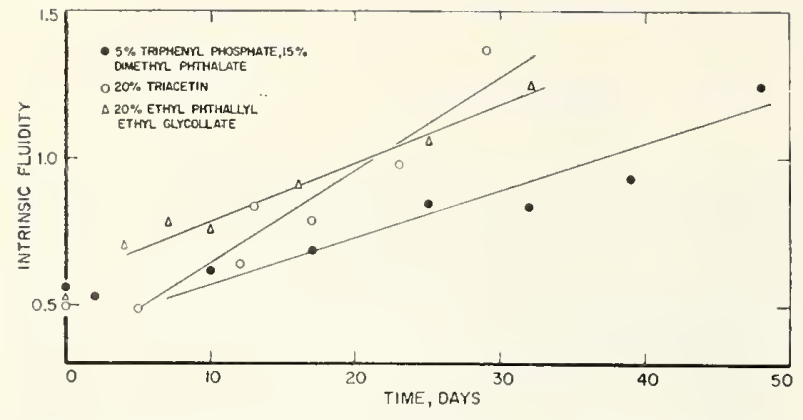

Figure 7. Degradation of experimental cellulose acetate films (1-mil thick) in moist oxygen at $124^{\circ} \mathrm{C}$; flake $A$ with various plasticizers.

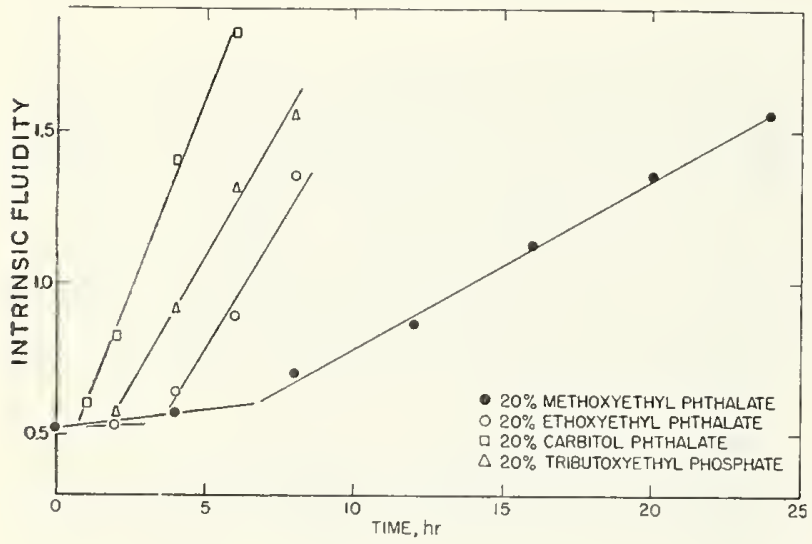

Figure 8. Degradation of experimental cellulose acetate films (1-mil thick) in moist oxygen at $124^{\circ} \mathrm{C}$; flake $A$ with various plosticizers.

Data on the effect of acid and of acid acceptors on the degradation of experimental cellulose acetate films are plotted in figure 9. Magnesium acetate acts as an acid acceptor and suppresses the degrading effect of sulfuric acid in the film. Acid can be present in a cellulose acetate film as an impurity from the manufacturing process as well as from atmospheric contamination.

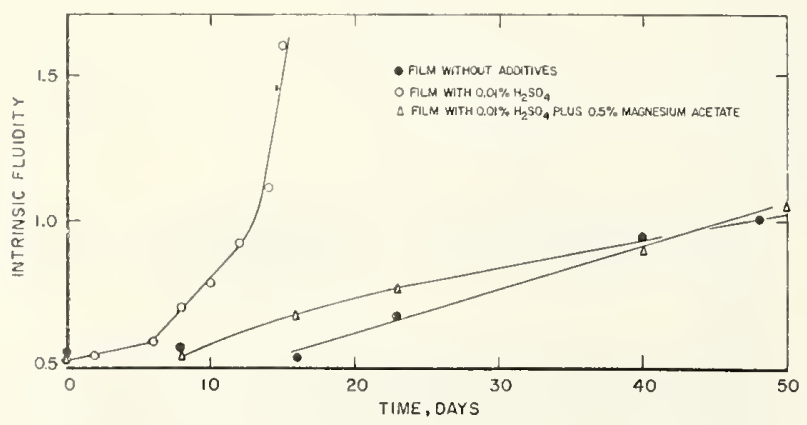

Figure 9. Degradation of experimental unplasticized cellulose acetate films (1-mil thick) in moist oxygen at $124^{\circ} \mathrm{C}$; flake $D$ with acid and acia acceptor.
Data on the degradation of an experimental film formulated especially for stability are plotted in figure 10. The stability of this film is far greater than that of any of the commercial or other experimental films for which data have been obtained. For maximum stability, a cellulose acetate film should contain plasticizers that do not contribute to degradation, an antioxidant, and an acid acceptor.

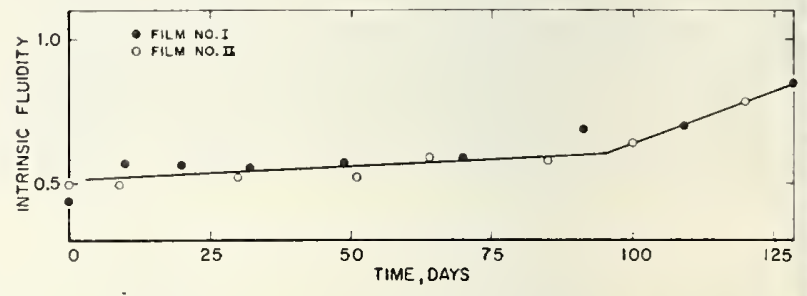

FIgURE 10. Degradaiion of an experimental cellulose acetate film (1-mil thick) in moist oxygen at $124^{\circ} \mathrm{C}$.

The samples are duplicates with the composition given in table 6 , footnote $b$.

\subsection{Plasticizer Loss of Cellulose Acetate Films}

\section{a. General}

The loss of plasticizer from plastic articles under service conditions is a very important consideration in formulation, and each article must be considel ed with respect to its particular end use. For many purposes a plastic has lost much or all of its utility if only a small percentage of the plasticizer is lost. For others, plasticizer loss is not so important.

An archival film must contain enough of an active solvent plasticizer to permit lamination to paper at a temperature low enough to keep degradation of the film and the paper at a low level. Since many documents repaired in this way are to be stored for several hundred years, it is important to have information on rate of plasticizer loss up to as near 100-percent loss as possible. It is also desirable to know something about the change in physical properties of the film after extensive loss of plasticizer.

Several laboratory tests have been devised to simulate the plasticizer loss that a plastic article might suffer in service. These have been adequately discussed elsewhere [4 through 8].

Several investigators have inquired into the mechanism of plasticizer loss. In a series of articles on migration of plasticizer in vinyl resins [9 through 12], the problem has been classified as "surface resistance controlling" and "vinyl resistance controlling," or diffusion controlling. The conditions of use determine whether plasticizer loss is surface controlling or diffusion controlling. Plasticizer loss from an archival film, which is approximately 1 mil thick, would be "surface controlling" if laminated documents were stored loosely with good ventilation. If several laminates 
were stored together, as in a book that had been laminated and rebound, plasticizer loss would be "diffusion controlling."

\section{b. Materials and Methods of Test}

The films used for weight loss study at various temperatures were prepared from a cellulose acetate flake with a degree of substitution of 2.3 and a viscosity (ASTM D 871-48, formula A) of 41 sec. Each film was formulated to contain 20.5percent plasticizer. The casting solvent was a mixture of 90-percent acetone and 10-percent methyl alcohol by volume. Three films were prepared, one containing dimethyl phthalate, one with diethyl phthalate, and the other with triphenyl phosphate.

The experimental film containing triphenyl phosphate and two commercial films, numbers 4 and 7 , were used in the study of the change in physical properties due to plasticizer loss in activated charcoal. The amount of plasticizer in the two commercial films was determined by the method of Whitnack and Gantz [13] using 50:50 absolute ethyl alcohol and $n$-hexane in a semimicro Soxhlet extractor. Film number 4 contained 26percent plasticizer, and film number 7 contained 29 percent plasticizer.

An ordinary oven with forced circulation was used at various temperatures for study of rate of plasticizer loss. The same oven was used for the weight loss experiments in activated charcoal at $50^{\circ} \mathrm{C}$. The film specimens were placed in a photographic tray and separated from each other with layers of charcoal. All physical tests were performed at $23^{\circ} \mathrm{C}$ and 50 -percent relative humidity.

\section{c. Results and Discussion}

Weight loss curves were obtained on the films containing dimethyl phthalate and diethyl phthalate, respectively, at $75^{\circ}, 90^{\circ}, 110^{\circ}$, and $125^{\circ} \mathrm{C}$. Weight loss curves on the film containing triphenyl phosphate were obtained at $110^{\circ}, 125^{\circ}$, and $140^{\circ}$ C. Typical curves for dimethyl phthalate and triphenyl phosphate are shown in figure 11. These curves all show a high rate of plasticizer loss in the early part of the curve, but an appreciable amount of the plasticizer is very tenaciously retained. Dimethyl phthalate and diethyl phthalate are active solvent plasticizer's for cellulose acetate; triphenyl phosphate is not.

In order to obtain more information on the nature of the weight loss curves, the data were analyzed using the time-ratio tables developed by Flynn [14]. From data on the degree of advancement of a rate process (plasticizer loss in this case) the exponent $n$ in the rate equation $d x / d t=k(1-x)^{n}$ may be estimated. In this case $x$ is the percent plasticizer disappearing in time $t, k$ is a constant, and $n$ is an exponent whose value is determined from the data. This analysis showed a definite difference between triphenyl phosphate and the

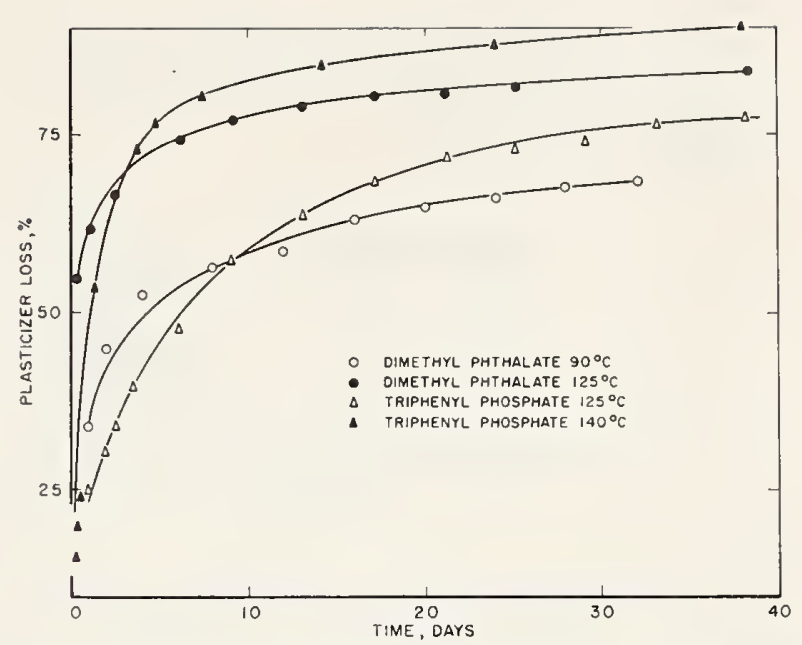

Figure 11. Typical plasticizer loss curves for cellulose acetate films (1-mil thick) formulated from flake $C$ and containing dimethyl phthalate or triphenyl phosphaie.

two active solvent plasticizers. The data on the loss of dimethyl and diethyl ph thalate give a value of $n$ of about 5 . Triphenyl phosphate gives a much higher value of $n$ (about 10 ) in the early par't of the plasticizer loss curve. By the time half of the plasticizer is gone, the value of $n$ is about 3 , and remains mostly between 2 and 3 up to about 80-percent plasticizer loss.

It appears that the two active solvent plasticizers would be retained very tenaciously by cellulose acetate in the last stages of plasticizer loss. For a film that is to be kept indefinitely, the use of triphenyl phosphate probably would offer little advantage over dimethyl phthalate with respect to weight loss.

The rate of plasticizer loss is plotted against $1 / T$ on semilog paper in figures 12,13 , and 14 . The slopes of the tangents to the plasticizer loss curves were taken as the rate at 50 -percent loss. A measure of the rate of plasticizer loss between 0 - and 25-percent loss was obtained from the slope of the secant between 0 and 25 percent. There are distinct differences in the activation energies of plasticizer loss at the two levels. Initially the activation energy, $E$, is of the order of 20 kcal for all three films. At the 50-percent level, the activation energy for the active solvent plasticizers is a little less than $30 \mathrm{kcal}$; for triphenyl phosphate it is about 40 kcal.

These values for activation energy are only approximate and must be considered as orders of magnitude. However, it is clear that the energy involved is more than one would expect from a simple evaporation process. Also, plasticizer loss becomes more temperature-dependent as the plasticizer is lost. These two facts make it clear that plasticizer loss from a cellulose acetate archival film probably could not be expected to go to completion. 


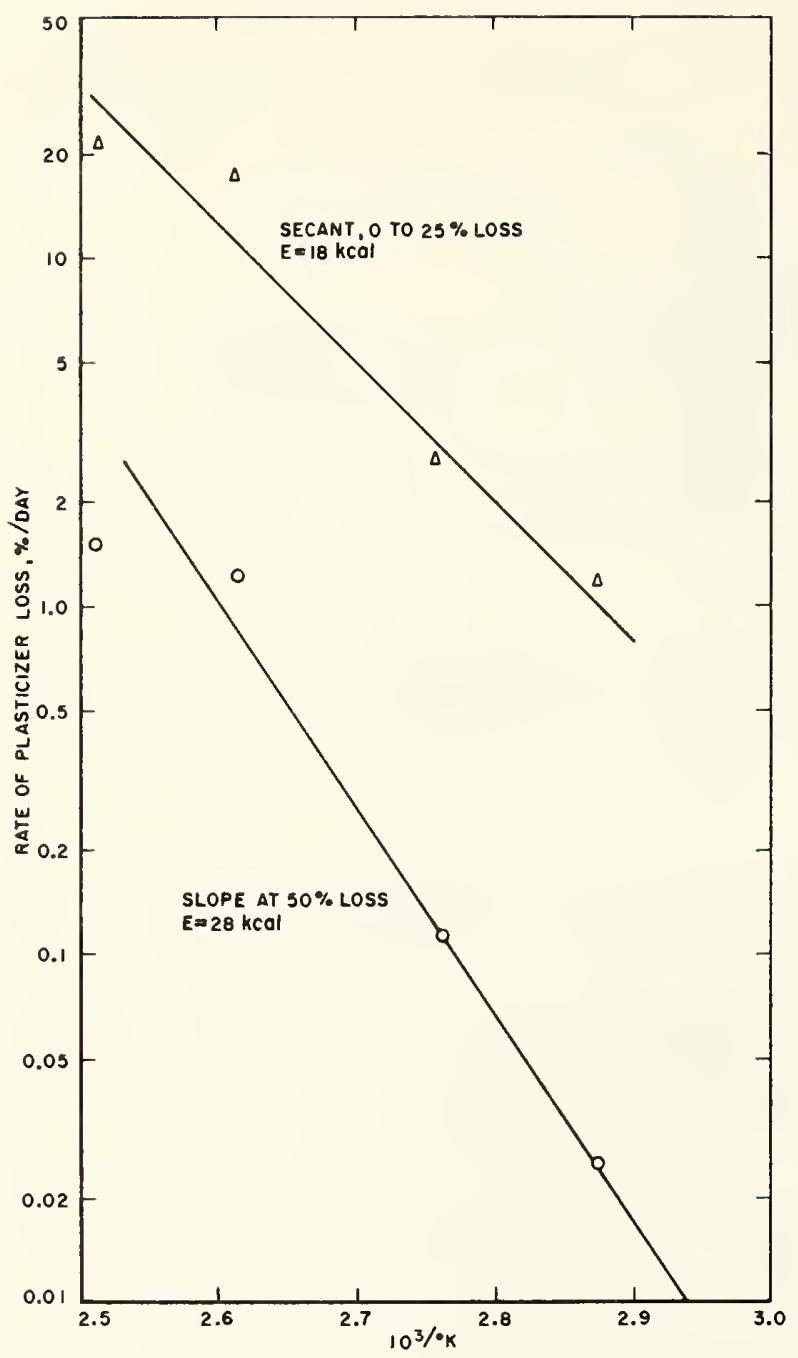

FIGURE 12. Arrhenius plots for the loss of dimethyl phthalate from a cellulose acetaie film (1-mil thick) formuiated from flake $C$.

An unplasticized cellulose acetate film 1 mil thick has sufficient flexibility for archival purposes. However, as a plasticizer is required initially to achieve lamination, the properties of films that have lost an appreciable amount of plasticizer should be examined. Unfortunately, heating a film at a temperature high enough to evaporate the plasticizer within a reasonable length of time also may cause physical changes in the film. In order to avoid this as much as possible, three films were heated at $50^{\circ} \mathrm{C}$ in activated charcoal. The latter absorbs the plasticizer and greatly accelerates the plasticizer loss. Data on weight loss and dimensional change are given in table 1 , and the data on dimensional change are plotted in figure 15 .

The plot of shrinkage against weight loss in figure 15 gives a fairly straight line for the three films. It appears that shrinkage is a function of weight loss, regardless of the type of plasticizer.

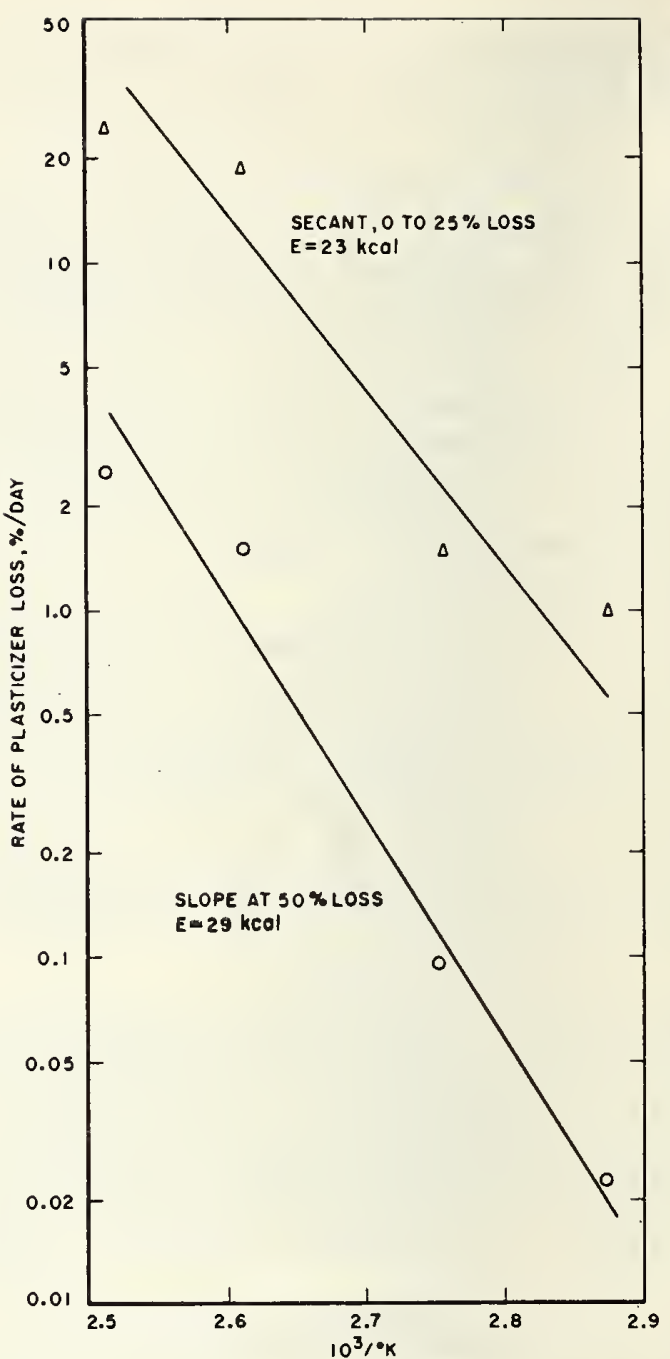

FIGURE 13. Arrhenius plots for the loss of diethyl phthalate from a cellulose acetate film (1-mil thick) formulated from flake $C$.

The weight loss values for films numbers 4 and 7 in table 1 represent about half of the plasticizer originally in the films. As the rate of plasticizer loss becomes very low at this point, the shrinkage values for unlaminated films would not exceed those in table 1 for many years. As the paper and tissue, if present, of laminated documents would tend to hold the cellulose acetate film in place and prevent full shrinkage, and as the process would occur over a period of many years, enough "creep" of the film should occur to relieve any strain due to potential shrinkage. Therefore, shrinkage should not be a problem.

Data on the shrinkage of laminated specimens of bond paper after aging in activated charcoal at $50^{\circ} \mathrm{C}$ are given in table 2 . It is obvious that tissue reduces the shrinkage to a remarkable degree. There is considerable difference in shrinkage between the long and the short directions of the specimens. 'This is probably due to differences 


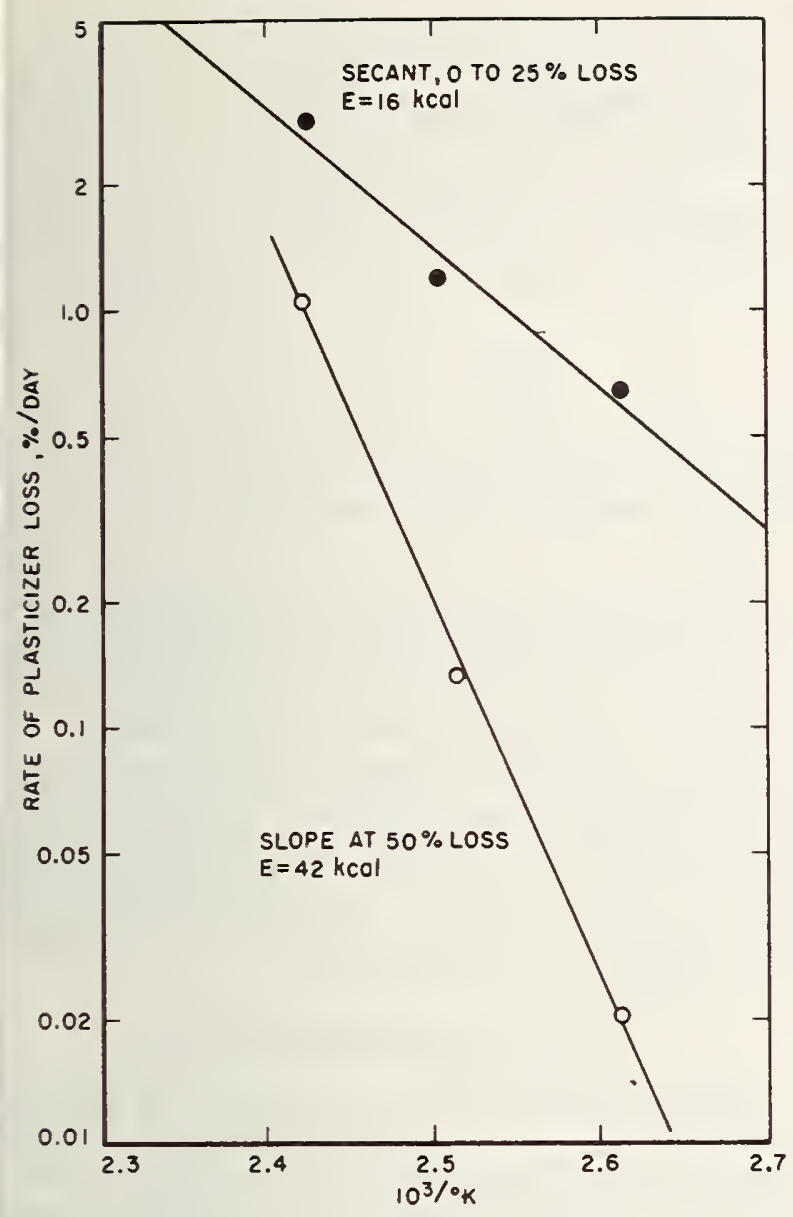

FIGURE 14. Arrhenius plots for the loss of triphenyl phosphate from a cellulose actate film (1-mil thick) formulated. from flake $C$.

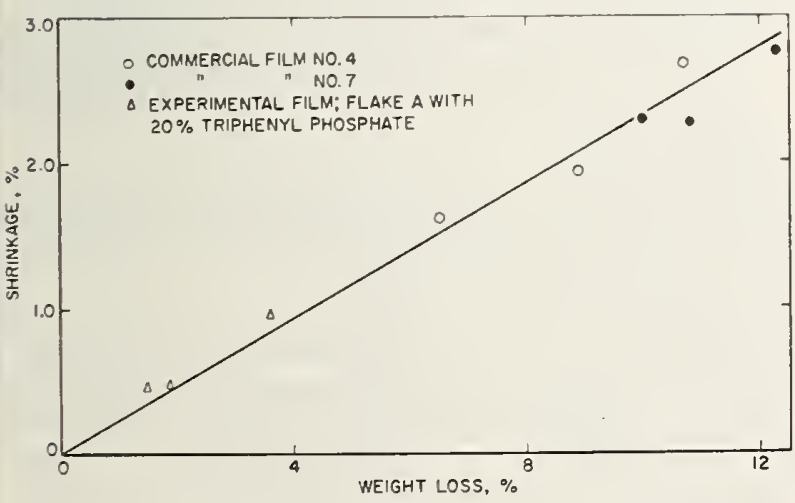

FIGURE 15. The shrinkage of plasticized cellulose acetate films (1-mil thick) as a function of weight loss.
TABLE 1. Weight loss and shrinkage of cellulose acetate films after aging in activated charcoal at $50^{\circ} \mathrm{C}$

\begin{tabular}{|c|c|c|c|}
\hline & $\begin{array}{c}\text { Commercial } \\
\text { film No. } 4\end{array}$ & $\begin{array}{c}\text { Commercial } \\
\text { film No. }\end{array}$ & $\begin{array}{l}\text { Experi- } \\
\text { mental } \\
\text { film * }\end{array}$ \\
\hline $\begin{array}{l}\text { Weight loss: } \\
\text { After } 5 \text { days_-_.......... percent_. } \\
\text { After } 16 \text { days } \\
\text { After } 46 \text { days }\end{array}$ & $\begin{array}{r}6.5 \\
8.9 \\
10.7\end{array}$ & $\begin{array}{l}10.0 \\
10.8 \\
12.3\end{array}$ & $\begin{array}{l}1.5 \\
1.9 \\
3.6\end{array}$ \\
\hline 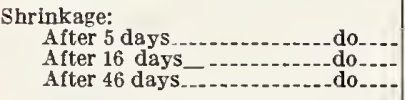 & $\begin{array}{l}1.63 \\
1.95 \\
2.69\end{array}$ & $\begin{array}{l}2.29 \\
2.27 \\
2.76\end{array}$ & $\begin{array}{l}.48 \\
.51 \\
.96\end{array}$ \\
\hline
\end{tabular}

${ }^{3}$ Made with cellulose acetate flake $A$, described in table 4 , and containing 20-percent triphenyl phosphate, hased on weight of film.

TABLE 2. Shrinkage of laminated specimens, with and without tissue, after aging in activated charcoal s

\begin{tabular}{|c|c|c|}
\hline Laminate tested & \multicolumn{2}{|c|}{$\begin{array}{l}\text { Percent shrinkage } \\
\text { after aging in ac- } \\
\text { tivated charcoal } \\
\text { at } 50^{\circ} \mathrm{C} \text { for: }\end{array}$} \\
\hline $\begin{array}{l}\text { Bond paper laminated with cellulose acetale film No. } 7 \\
\text { only. }\end{array}$ & \multirow{5}{*}{$\begin{array}{r}14 \text { days } \\
\\
0.6 \\
.2 \\
.6 \\
.4\end{array}$} & \multirow{5}{*}{$\begin{array}{r}80 \text { days } \\
\\
0.8 \\
.2 \\
.8 \\
.4\end{array}$} \\
\hline $\begin{array}{l}\text { Paper edge to edge: } \\
\text { Cross direction.. }\end{array}$ & & \\
\hline & & \\
\hline Film ed & & \\
\hline $\begin{array}{l}\text { Cross direction } \\
\text { Machine direction }\end{array}$ & & \\
\hline \multicolumn{3}{|l|}{$\begin{array}{l}\text { Bond paper laminated with cellulose acetate film No. } 7 \\
\text { and tissue. }\end{array}$} \\
\hline Cro & \multirow{2}{*}{.2} & \multirow{2}{*}{.4} \\
\hline edge: $b$ & & \\
\hline end ene. & .2 & .4 \\
\hline Machine direction & 2 & \\
\hline
\end{tabular}

s Data were obtained by James Gear, National Archives and Records Serrice. Specimens were approximately $14 \times 23 \mathrm{~cm}$.

b The film, or film and tissue, of the laminated specimens extended ahout $0.3 \mathrm{~cm}$ beyond the edge of the paper.

in the machine and cross directions of the paper.

Stress-strain data and folding endurance data have been obtained on the films heated in charcoal and are given in table 3 . None of the properties of interest in an archival film has changed enough to be considered significant. The experimental film plasticized with triphenyl phosphate showed a significant decrease in elongation at break and energy to rupture. The former is not particularly important, but it is tied up with the latter, which, it is felt, is important in determining edge tear. However, this formulation is not representative of archival films.

\subsection{Physical Properties of Cellulose Acetate Films}

\section{a. General}

The physical properties of a cellulose acetate laminating film are fairly closely defined by the plasticizer requirement. An unplasticized film has a very high softening temperature, and it is 
TABLE 3. Physical properties of cellulosc acetate films beforc and after heating in charcoal for 46 days at $50^{\circ} \mathrm{C}$

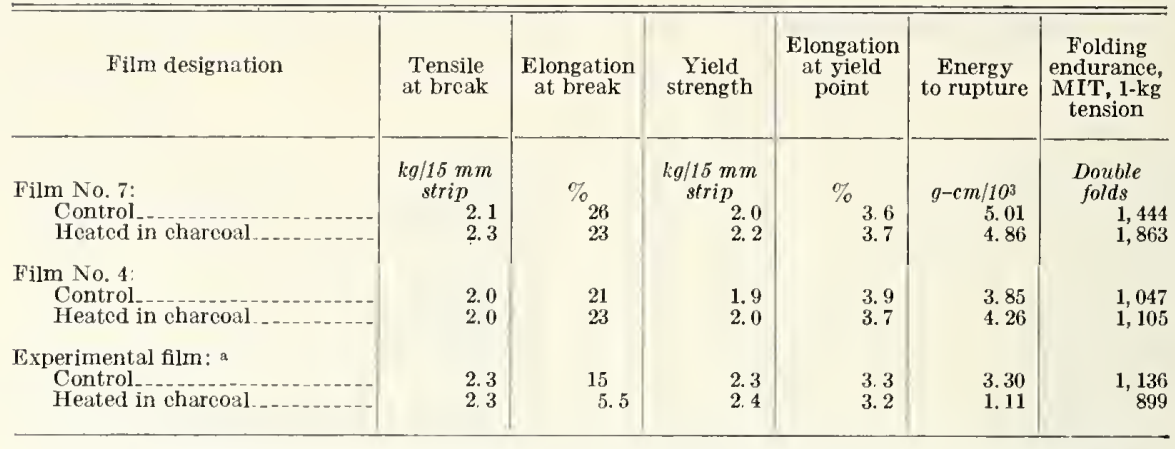

a Made with ecliulose acctate flake $\Lambda$ described in table 4 and containing 20-percent triphenyl phosphate, based on weight of film.

necessary to formulate the cellulose acetate with an active solvent plasticizer in order to reduce the softening temperature enough to allow lamination without damage to the film or the doenment.

A typical load-elongation curve for plasticized cellulose acetate is shown in figure 16. The load is the pull in kilograms on a strip of film in an automatic recording tensile testing machine, and the elongation is the amount of stretch as the pulling force is applied. The first part of the curve up to the yield point mostly represents clastic behavior, and if the load were removed, the film would essentially go back to its original length. If the load is removed beyond the yield point and before the breaking strength is reached, the specimen will have a permanent set and will not go back to its original length.

The elongation of plasticized collulose acetate film is approximately 3 percent at the yield point. The extent to which paper may be elongated without rupture varies with the paper and with the direction of stretch, but is usually between 1 and 4 percent. Therefore, the elongation of the paper and the elongation of the film that would be useful in protecting the body of the document are fairly well matched.

The area under the load-elongation curve is a function of the energy required to rupture the

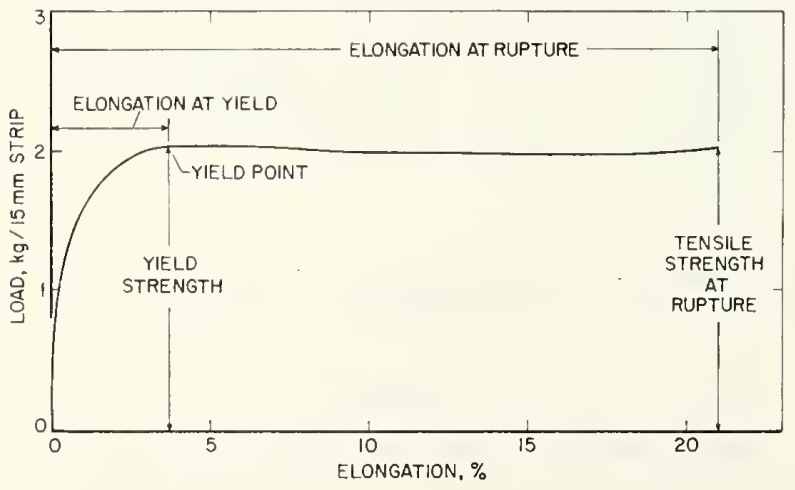

F1GURE 16. Typical load-elongation curve for plasticized cellulose acetate film (1-mil thick). specimen, and is a measure of the toughness of the film. Before full advantage could be taken of its toughness, the film would have acquired a permanent set and the paper would have been torn.

Many properties of films, such as edge tear, toughness, tensile strength and elongation, depend on the condition of the edge of the film. A small defect or notch can result in considerable impairment of film properties. Plastic films in general have a high edge tear in comparison with internal tear, which is usually very low.

\section{b. Materials and Methods of Test}

Physical test data were obtained on several experimental films and commercial films. With one exception, the experimental films were plasticized with 20-percent dimethyl phthalate, and were cast from a solution of $16-\mathrm{g}$ cellulose acetate and $4-\mathrm{g}$ plasticizer in $180-\mathrm{ml}$ acetone and $20-\mathrm{ml}$ methyl alcohol. Flake $B$ was dissolved in $180-\mathrm{ml}$ methylene chloride and 20-ml methyl alcohol. All films were conditioned at $23^{\circ} \mathrm{C}$ and 50-percent relative humidity for at least two days before testing.

Edge tear was determined according to ASTM method D 1004 on specimens cut with a special die, and is the force in kilograms required to start a tear in the specimen.

Folding endurance data were obtained with an MIT tester at $1-\mathrm{kg}$ tension according to TAPPI Standard T 423.

Tensile load-elongation data ${ }^{2}$ were obtained with a constant-rate-of-straining machine with an initial jaw separation of $4 \mathrm{in}$. The rate of motion of the crosshead was $2 \mathrm{in} . / \mathrm{min}$.

A modification of ASTM D 903, Peel or Stripping Strength of Adhesives [16], was used for the evaluation of lamination efficiency. A shect of commercial cellulose acetate laminating film was laminated between two sheets of a strong, hard, bleached sulfate paper ${ }^{3}$ with the paper

21Data were obtained by Russell J. Capott.

31Made in the paper mill at the National Bureau of Standards, mill run No. 1882 . 
extending about $10 \mathrm{~cm}$ beyond the film at one end of the sandwich. Strips $15-\mathrm{mm}$ wide were cut from this sandwich, and one end of each strip of paper was placed in the clamps of an automatic recording tensile testing machine. The load value at the beginning of failure was always the highest, failure occurring between the film and one strip of paper which then tore and feathered out to rupture.

\section{c. Results and Discussion}

Physical test data on several experimental films and commercial films are given in table 4. The degree of substitution of the cellulose acetate samples varies from 2.31 to 2.68 and the viscosity varies over a wide range, but most of the physical properties fall within fairly narrow limits. The commercial cellulose acetate films have a bigher elongation at break than the experimental films and a much higher energy to rupture.

Some of the experimental films gave considerably lower folding endurance values than did the commercial films. The unplasticized experimental film exhibited an unusually high folding endurance, indicating that cellulose acetate films 1-mil thick do not depend on plasticizers for flexibility. Unplasticized cellulose acetate films 3 -mils thick may exhibit a folding endurance of several hundred double-folds [15].

In order to obtain an estimate of the intrinsic fluidity at which a cellulose acetate film is no longer useful, specimens of commercial film number 4 were aged in oxygen for $8,16,24$, and 40 $\mathrm{hr}$, and in nitrogen for 24 and $40 \mathrm{hr}$. Intrinsic fluidity values and load-elongation data are given in table 5 and typical load-elongation curves are given in figure 17 . There are no signif-

TABLE 4. Physical properties a of cellulosc acetate, polyethylene, and polyethylenc terephthalate films

\begin{tabular}{|c|c|c|c|c|c|c|c|c|c|c|}
\hline Material tested & $\begin{array}{l}\text { Degree of } \\
\text { substitu- } \\
\text { tion }\end{array}$ & Viscosity & $\begin{array}{l}\text { Tensile } \\
\text { strength } \\
\text { at break }\end{array}$ & $\begin{array}{l}\text { Elonga- } \\
\text { tion at } \\
\text { break }\end{array}$ & $\begin{array}{l}\text { Yield } \\
\text { strength }\end{array}$ & $\begin{array}{l}\text { Elonga- } \\
\text { tion at } \\
\text { yield }\end{array}$ & $\begin{array}{l}\text { Energy to } \\
\text { rupture }\end{array}$ & $\begin{array}{c}\text { Folding } \\
\text { endurance, } \\
\text { MIT, 1-kg } \\
\text { tension }\end{array}$ & $\begin{array}{c}\text { Edge tear } \\
\text { (ASTM D } \\
1001)\end{array}$ & Thickness \\
\hline
\end{tabular}

Experimental film ${ }^{b}$ made with cellulose acetate

\begin{tabular}{|c|c|c|c|c|c|c|c|c|c|c|}
\hline $\begin{array}{l}\text { Flake } \\
\text { A } \\
\text { B }-1 \\
\text { D } \\
D=6\end{array}$ & $\begin{array}{l}2.44 \\
2.68 \\
2.31 \\
2.41 \\
2.41\end{array}$ & $\begin{aligned} & \text { e } 51 \\
& \text { d } 165 \\
& \text { c } 41 \\
& \text { - } 69 \\
& \text { c } 69\end{aligned}$ & $\begin{array}{r}\mathrm{kg} / \mathrm{l} 5-\mathrm{mm} \\
\text { strip } \\
2.0 \\
2.5 \\
\because \quad 2.4 \\
2.5 \\
3.0\end{array}$ & $\begin{array}{l}\% \\
6.2 \\
5.4 \\
6.4 \\
8.3 \\
4.3\end{array}$ & $\begin{array}{r}\text { kg/15-mm } \\
\text { strip } \\
2.0 \\
2.5 \\
2.4 \\
2.6 \\
3.0\end{array}$ & $\begin{array}{l}\% \\
3.1 \\
3.1 \\
3.2 \\
3.2 \\
3.2\end{array}$ & $\begin{array}{r}g-c m / 10^{3} \\
1.03 \\
1.18 \\
1.34 \\
1.90 \\
1.10\end{array}$ & $\begin{array}{r}\text { Double } \\
\text { folds } \\
511 \\
919 \\
506 \\
806 \\
1,393\end{array}$ & $\begin{array}{r}g \\
205 \\
105 \\
90 \\
135\end{array}$ & $\begin{aligned} & \text { mil } \\
& 1.5 \\
& 1.5 \\
& 1.5 \\
& 1.5 \\
& 1.1\end{aligned}$ \\
\hline 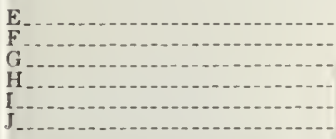 & $\begin{array}{l}2.49 \\
2.41 \\
2.40 \\
2.41\end{array}$ & $\begin{array}{l}\cdot 23 \\
\cdot 30 \\
e 44 \\
\text { e } 62\end{array}$ & $\begin{array}{l}2.3 \\
2.2 \\
2.0 \\
2.5 \\
2.4 \\
2.4\end{array}$ & $\begin{array}{l}7.4 \\
6.5 \\
6.2 \\
7.3 \\
5.9 \\
6.8\end{array}$ & $\begin{array}{l}2.5 \\
2.2 \\
2.1 \\
2.6 \\
2.5 \\
2.5\end{array}$ & $\begin{array}{l}\text { 3. } 2 \\
3.1 \\
3.0 \\
\text { 3. } 3 \\
\text { 3. } \\
\text { 3. }\end{array}$ & $\begin{array}{l}1.56 \\
1.20 \\
1.15 \\
1.70 \\
1.30 \\
1.49\end{array}$ & $\begin{array}{r}732 \\
922 \\
1,148 \\
750 \\
846 \\
1,297\end{array}$ & $\begin{array}{r}115 \\
85 \\
160 \\
115 \\
170 \\
90\end{array}$ & $\begin{array}{r}1.5 \\
1.5 \\
1 .-1.5 \\
1.5 \\
1.2 \\
1.2\end{array}$ \\
\hline
\end{tabular}

Commercial films

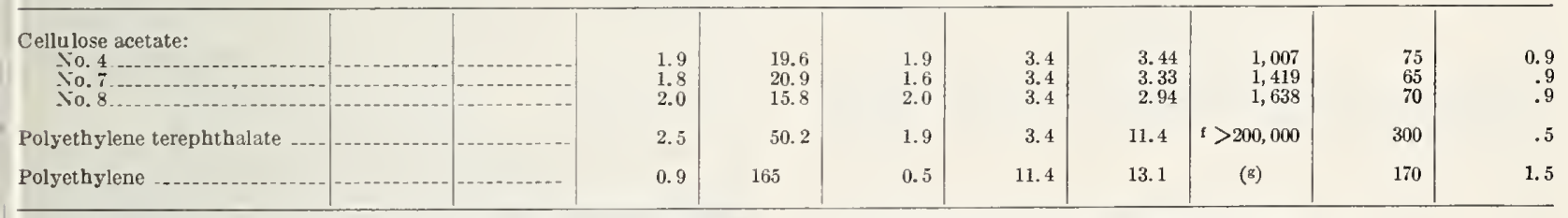

- Data were obtained with 10 specimens cut in the long direction of the film. b All exper imental films contained 20 percent by weight of dimethyl phthalate, except $\mathrm{D}^{*}$ which was unplasticized.

ASTM method D 871, solvent A, manufacturer's data. d ASTM D 871 , solvent C, manufacturer's data.
e ASTM method D 871, solvent B, manufacturer's data.

i Test discontinued after 200,000 folds.

\& Specimens elongated too much to obtain fold data.

TABLE 5. Correlation of intrinsic fuidity with physical properties of cellulose acetate film No. 4

\begin{tabular}{|c|c|c|c|c|c|c|}
\hline Treatment of film & $\begin{array}{c}\text { Tensile } \\
\text { at breaks }\end{array}$ & $\begin{array}{l}\text { Elongation } \\
\text { at break }\end{array}$ & $\begin{array}{l}\text { Yield- } \\
\text { strengtha }\end{array}$ & $\begin{array}{l}\text { Elongation } \\
\text { at yield }\end{array}$ & $\begin{array}{c}\text { Energy } \\
\text { to ruptures }\end{array}$ & $\begin{array}{l}\text { Intrinsic b } \\
\text { fluidity }\end{array}$ \\
\hline Ľntreated.... & $\begin{array}{r}k g / 1 \bar{b}-m m \\
\text { strip } \\
1.8\end{array}$ & ${ }^{\%}{ }_{11.2}$ & $\begin{array}{l}\mathrm{kg} / 15-\mathrm{mm} \\
\text { strip } \\
1.8\end{array}$ & ${ }^{\%} 3.5$ & $\begin{array}{r}g-c m / 10^{3} \\
1.86\end{array}$ & 0.59 \\
\hline $\begin{array}{l}\text { Nitrogen at } 124^{\circ} \mathrm{C} \text { : } \\
\quad 24 \mathrm{hr} \\
40 \mathrm{hr}\end{array}$ & $\begin{array}{l}1.4 \\
1.7\end{array}$ & $\begin{array}{r}6.5 \\
13.9\end{array}$ & $\begin{array}{l}1.4 \\
1.6\end{array}$ & $\begin{array}{l}3.0 \\
3.0\end{array}$ & $\begin{array}{l}0.98 \\
2.10\end{array}$ & $\begin{array}{l}.63 \\
.58\end{array}$ \\
\hline $\begin{array}{l}\text { Oxygen at } 124^{\circ} \mathrm{C}: \\
8 \mathrm{hr} \\
16 \mathrm{hr} \\
24 \mathrm{hr}\end{array}$ & $\begin{array}{l}1.5 \\
1.5 \\
0.9\end{array}$ & $\begin{array}{r}11.9 \\
4.0 \\
1.0\end{array}$ & $\begin{array}{l}1.5 \\
1.5\end{array}$ & $\begin{array}{l}3.2 \\
2.9\end{array}$ & $\begin{array}{r}1.68 \\
0.51 \\
.06\end{array}$ & $\begin{array}{r}.66 \\
.75 \\
1.12\end{array}$ \\
\hline
\end{tabular}

A verage for 20 specimens.

b. A verage for 3 or 4 specimens. 


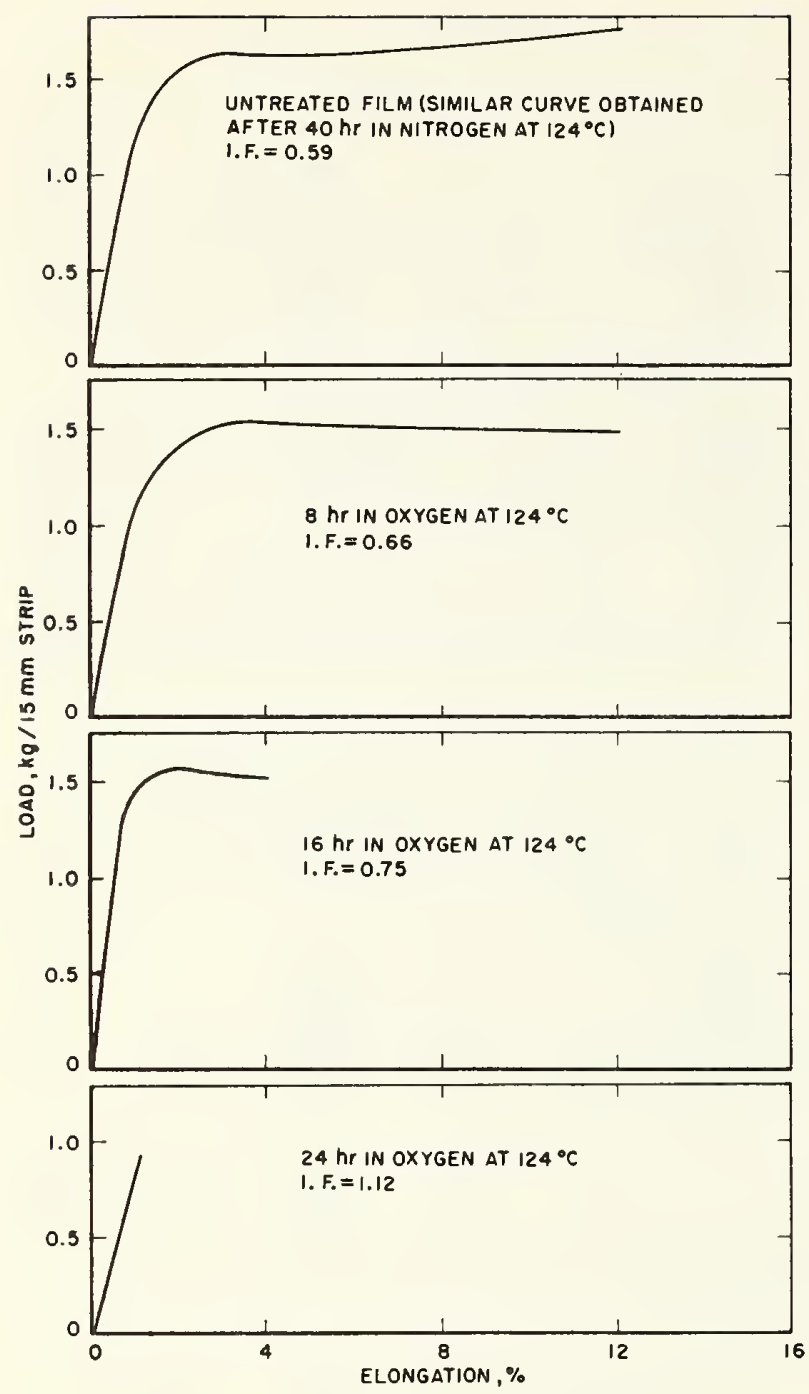

FIGURE 17. Tensile load-elongation curves for cellulose acetate film No. 4 (1-mil thick) at various intrinsic flutdities (I.F.).

icant changes in the films heated in nitrogen. A significant increase in intrinsic fluidity has occurred after $16 \mathrm{hr}$ in oxygen, and the elongation at break and the energy values have decreased greatly. After $24 \mathrm{hr}$ in oxygen the intrinsic fluidity values average 1.12 and the load-elongation data indicate that the film is practically useless.

From the data given above, it is obvious that as the intrinsic fluidity of a plasticized cellulose acetate film increases, the elongation at break and the energy to rupture deteriorate first. When the value for elongation at break has decreased to the point where it becomes equal to the elongation at the yield point, the tensile strength starts to deteriorate. From an inspection of the data in table 5 and the load-elongation curves in figure 17 , the intrinsic fluidity of a cellulose acetate film for archival use should not be greater than 0.66 .

To evaluate lamination efficiency, samples were laminated at $400 \mathrm{lb} / \mathrm{in} .^{2}$ at various temperatures on a flatbed press, and the force to start peeling the paper from the film was determined. The data are plotted in figure 18. As one would expect, the strength of the bond increases with temperature of lamination.

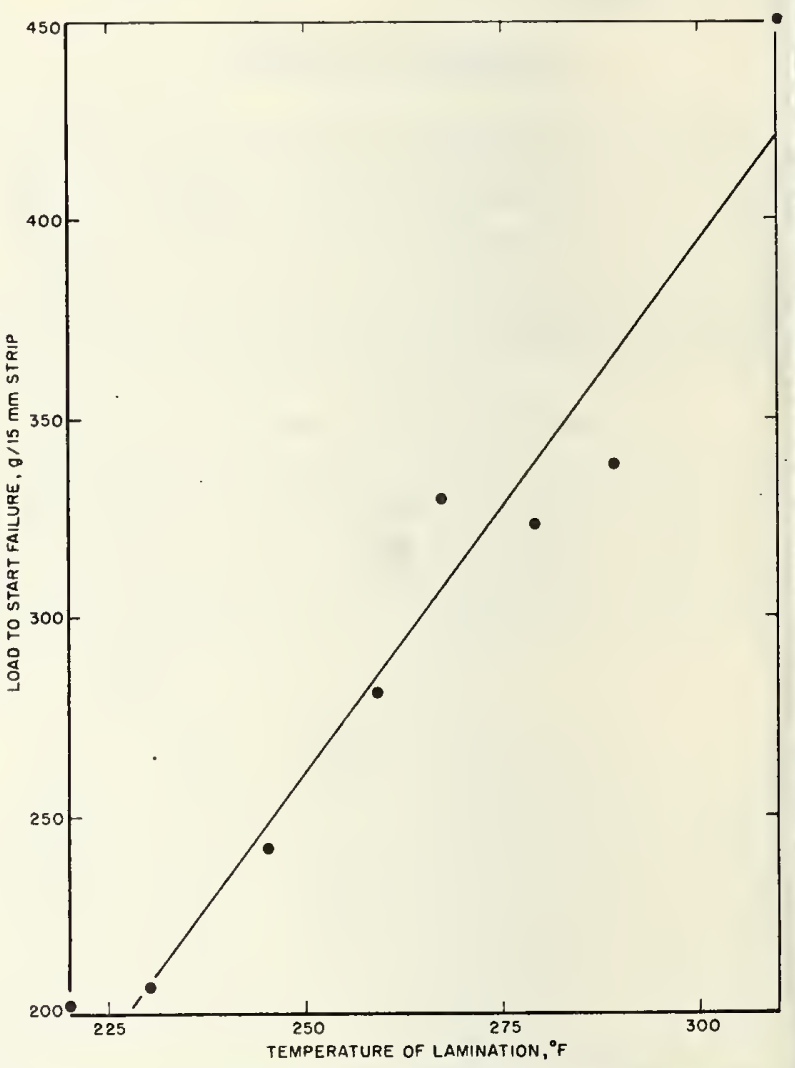

FigURE 18. Strength of bond between paper and a commercial cellulose acetate laminating film versus temperature of lamination.

In order to evaluate various films for lamination, it is desirable to be able to determine or to calculate the softening temperature of the film. Softening temperature is difficult to determine or to specify, as the values depend on the method of measurement. In one method the film is heated on a copper block at a rate of $15^{\circ} \mathrm{C}$ per minute, and the temperature at which the film becomes limp is defined as the softening temperature [18]. In the method of Moelter and Schweizer [19] a creep test is used in which the film is held under tension during heating at a constant rate of $2^{\circ} \mathrm{C}$ per minute. Graphical treatment of the creep data gives the softening temperature. Moelter and Schweizer obtained data on several plasticizers, calculated the softening point depression constant for several types of plasticizer, and developed the equation $t=t_{0} e^{-k n}$ from the experimental dota. In this equation $t$ is the softening temperature in deg $\mathrm{C}$ of a film containing $n$ moles of plasticizer, $t_{\mathrm{o}}$ is the softening temperature of 
the acetate flake, and $k$ is the softening point depression constant for the plasticizer.

Using this equation, the softening temperatures of four of the more promising films were calculated, and the data are given in table 6 . These data suggest that a softening temperature near $114^{\circ} \mathrm{C}$ would be desirable, as the first three films laminate satisfactorily while the last one does not.

\section{Degradation of Film and Paper During Lamination}

The degradation of film and paper during the lamination process was studied on three laminating presses in the Washington area. Specimens of film of proper weight for the viscosity test were placed in folds of aluminum foil and run through the presses. Two commercial films showed no measurable change in viscosity even aftel 20 passes in a press.

Samples of rag paper were run through the presses in the same manner as the films, except that the aluminum foil was omitted. 'The paper' had a $p \mathrm{H}$ of 4.9 , cold extraction. Some of this paper was treated with alum to give a $p \mathrm{H}$ of 3.9 , cold extraction. Viscosity in cuprammonium hydroxide solution was determined before and after the specimens had been run through the presses, and the degree of polymerization $(D P)$ calculated from the viscosity data. The data are given in table 7.

TABLE 6. Calculated softening temperatures of typical cellulose acetate laminating films ${ }^{\text {a }}$

\begin{tabular}{c|c}
\hline \multicolumn{1}{c|}{ Film designation } & $\begin{array}{c}\text { Softening } \\
\text { temperature }\end{array}$ \\
\hline & ${ }^{\circ} \mathrm{C}$ \\
Commercial film No. 4 & 113.5 \\
Commercial film No. 7.5 & 114 \\
\hline Experimental film No. 2 berimental film No. 3 o & 127.5
\end{tabular}

- Softening temperatures were calculated using the equation: $t=t_{0} e^{-k n}$ (see p. 10).

b Composition of flim No. 2:

73 percent cellulose acetate flake $\mathbf{E}$,

5 pereent triphenyl phosphate,

20 percent dimethyl phthalate,

0.5 percent magneslum acetate tetrahydrate,

1.0 percent resorcinol monobenzoate,

0.5 percent di-tert-butyl $p$-cresol.

- Composition same as No. 2 except that the film contains 15 percent d1methyl phthalate and 78 percent cellulose acetate. Films Nos, 2 and 3 were supplied by W. D. Palst of Celanese Corporation of America.

The untreated specimens do not show an appreciable change after one pass in any of the presses. There are definite changes after 20 passes, both in $D P$ and in color. The color changes show good correlation with the changes in $D P$.

The specimens treated with alum to give a $p \mathrm{H}$ of 3.9 show drastic deterioration even after one pass. The $D P$ tests were made a few weeks after' the papers were treated, and it is obvious that some degradation occurred at room temperature. Enough acid was released during the short time in the press to degrade the cellulose to its leveling-off degree of polymerization. A graph illustrating the latter is shown in figure 19 .
TABLE 7. Degradation of rag paper in laminating presses

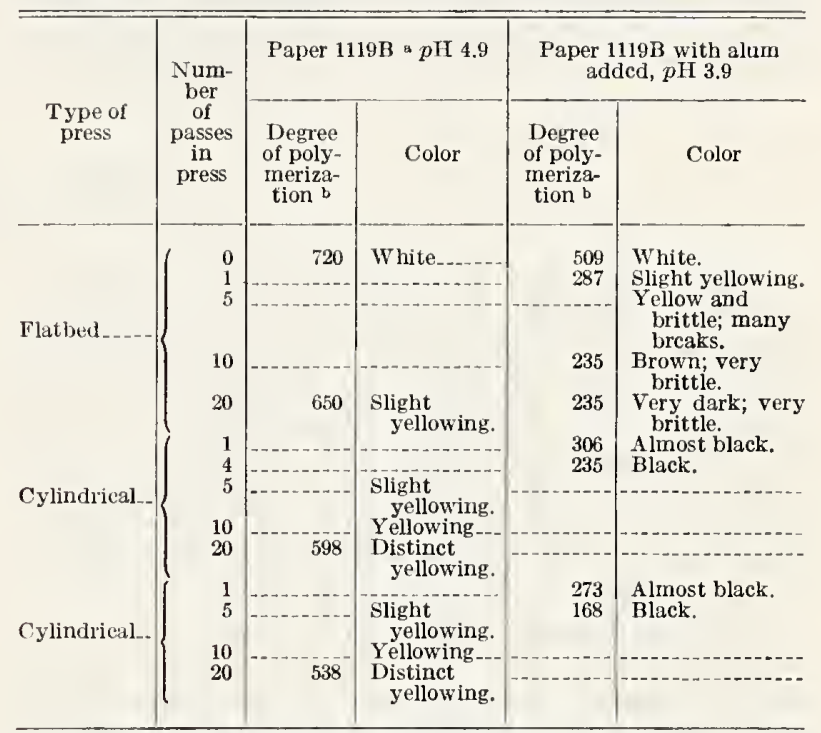

a Paper 1119B was made in the NBS paper mill from a mixture of now and old rags; it contains 1.5-percent rosin and 1.5-percent alum.

$b$ The degree of polymerization is the number of anhydroglucose units per cellulose molecule.

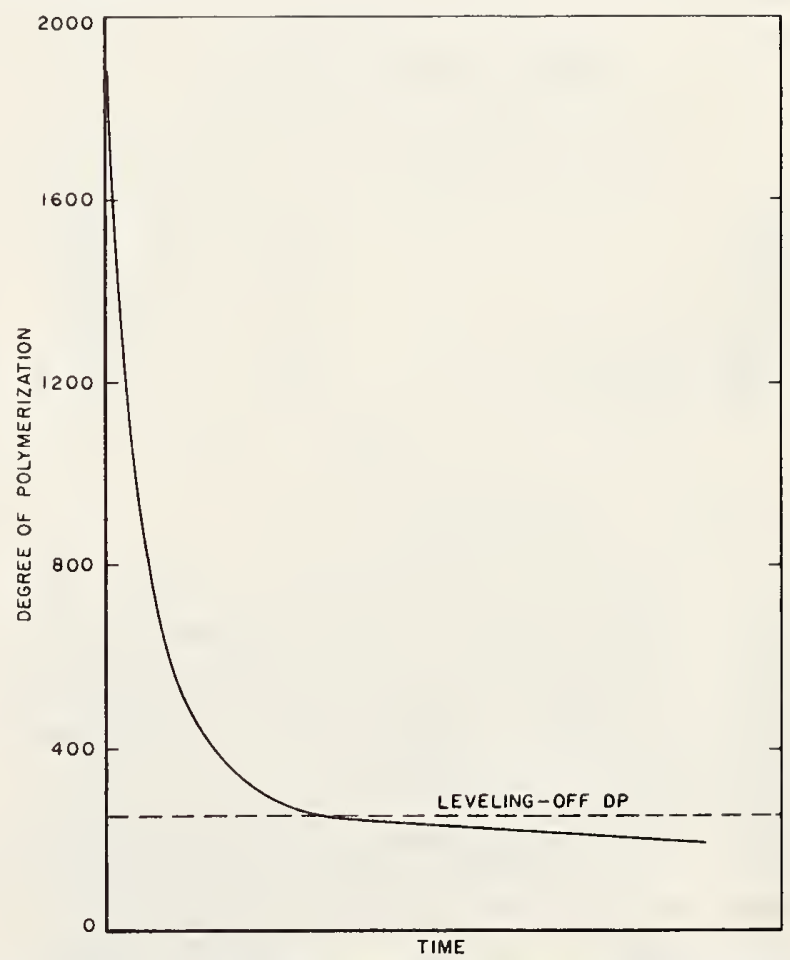

FIGURE 19. Leveling-off degree of polymerization of a cotton cellulose. The time scale depends on the temperature and the acid concentration. 
Cellulose is known to consist of crystalline and amorphous areas. Although the amorphous areas are accessible to water and acid, and are easily hydrolyzed, the crystalline areas are not penetrated by water. The hydrolyzing, or depolymerizing, effect of acid is very rapid in the amorphous areas, but, as the acid presumably can act only on the surface of the crystals, the action on them is very slow. The $D P$ value that prevails when the fast reaction in the amorphous areas is over and only the slow reaction with the crystals is occurring is termed the leveling-off $D P$. The leveling-off $D P$ of cotton is about 200 to 250 . Wood pulps may be higher or lower, depending on the source, and regenerated celluloses usually run from 15 to 60 .

The data obtained show that papers containing acid can be seriously degraded during lamination. Lamination does not degrade film or papers that contain little or no acid.

\section{Tissue Reinforcement}

Tissue has been used for years to strengthen laminated documents. In order to determine as quantitatively as possible the actual contribution of tissue to the properties of a laminate, several specimens were laminated according to a predetermined pattern. Paper, film, and tissue are all anisotropic in nature; that is, the physical properties depend on the direction of measurement. However, as the film is only nildly anisotropic, the film direction was kept constant.

The papel's used (table 8) were selected because: (1) the acid content was too small to cause degradation during lamination, and (2) the paper's were very weak, especially paper 1216, and any advantage of tissue reinforcement should be inore apparent. Commercial film No. 7 was used in these experiments.

TABLE 8. Composition and properties of papers a used in the study of tissue reinforcement

\begin{tabular}{|c|c|c|}
\hline Composition and properties & $\begin{array}{c}\text { Paper } \\
1214\end{array}$ & $\begin{array}{c}\text { Paper } \\
1216\end{array}$ \\
\hline $\begin{array}{l}\text { Fiber } \\
\text { Filler } \\
\text { Rlumin } \\
\text { Alpha cellulose } \\
\text { pH, cold extraction } \\
\text { Thickness } \\
\text { Folding endurance, M } 1 \mathrm{~T}, 0.5 \mathrm{~kg} \text { : } \\
\quad \text { Machine direction } \\
\text { Cross direction }\end{array}$ & $\begin{array}{l}\text { Old rag } \\
\text { None } \\
1.1 \\
0.5 \\
90.3 \\
6.2 \\
3.8 \\
524 \\
267\end{array}$ & $\begin{array}{l}\text { Old rag } \\
28.2 \\
\text { None } \\
\text { None } \\
92.7 \\
9.5 \\
3.3 \\
28 \\
25\end{array}$ \\
\hline
\end{tabular}

a These papers were madc in NBS paper mill.

b Precipitated calcium carbonate.

The laminations were performed by personnel at two different agencies, one of which uses a steam-heated flat-bed hydraulic press and the other a cylindrical press with electrically heated preheater platens. Laminations on the hydraulic press were done at a pressure of $300 \mathrm{lb} / \mathrm{in}^{2}{ }^{2}$ with steam applied to the press for 135 sec.; the steam pressure rose to about $74 \mathrm{lb}\left(152^{\circ} \mathrm{C}\right)$ in about 1 min. The pressure used on the cylindrical type press was not measured. The lamination sandwich was kept in the preheater 20 to $30 \mathrm{sec}$. before it was passed through the unheated pressure rollers. From previous measurements, it is estimated that the temperature of the preheater was approximately $182^{\circ} \mathrm{C}$.
A modification of the Finch edge-tear device (TAPPI standard $\mathrm{T} 470$ ) was developed for the evaluation of edge tear. The Finch device is used in the lower jaw of a tensile machine, and concentiates the stress on each side of a test strip of paper'. The modification concentrates the stress at only one edge of the specimen. The Finch attachment and the modification are shown in figure 20. The lower end of the specimen is clamped behind a $1 / 8-i n$. thick metal angle that is about $22 \frac{1}{2}$ from the horizontal. Tre tearing edge was dressed to a highly polished half-round. The dimensions are purely arbitrary as any edge-tear test is a modified tensile test with a high stress concentration at the edge of the test specimen. Because of elongation of the specimen, an edgetear value will depend on the angle of the tearing device, as the angle determines the stress concentration at the edge. A zero angle would correspond to the usual tensile test.

Data on the effect of width of extension of film or of film plus tissue on edge tear, using the modified Finch attachment, are given in table 9 . The width of extension of film on the paper and film laminate is not critical above $1 \mathrm{~mm}$. If the film does not extend beyond the edge of the paper, the edge tear is considerably lower. The width of extension of film plus tissue on the laminate of paper, film, and tissue is not critical. It is obvious that tissue decreases the edge tear of a laminate. The values in the last column are consistent with the value for the edge tear of film and tissue. It must be emphasized that the laminates containing tissue have a higher edge tear than the paper alone.

Laboratory data are not available on the abrasion resistance of documents laminated with and without tissue. Resistance to edge tear does not necessarily correlate with resistance to abrasion at the edge of the laminate.

Data on tensile strength, edge tear, internal tear, and elongation at break of paper, film, tissue, and various combinations of film with paper and tissue are given in table 10 . The data show few significant interactions. There is no significant interaction between the values for film and paper and the laminates of film and paper. However, considerable in teraction occurs when tissue is added to the laminate. 

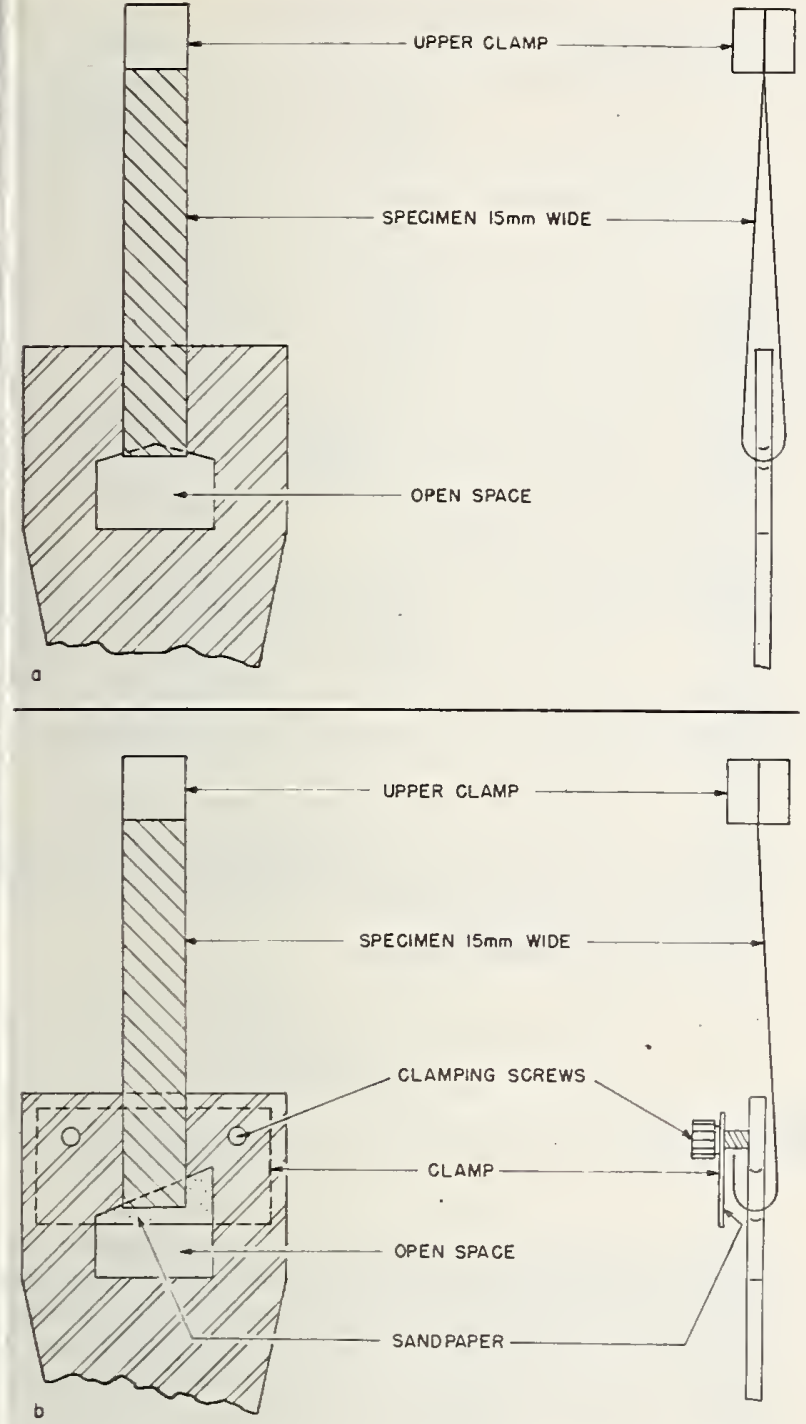

F1GURE 20. Sketches of (a) the Finch device for determining the edge tear of paper and of $(b)$ the modification developed for testing laminated papers.

TABLE 9. Edge lear of laminates a using the modified Finch method. Effect of extension of film or film and tissue on specimens made with paper 1216 and cellulose acetate film No. 7

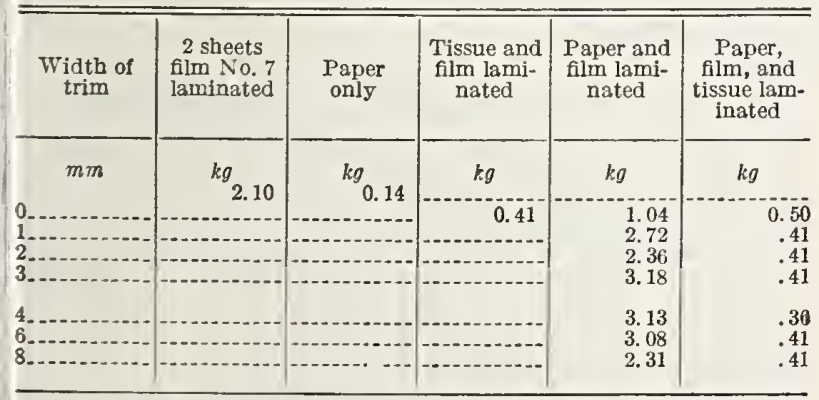

- Laminated on a flatbed press.
TABLE 10. Physical properties of various combinations of paper, film and tissue

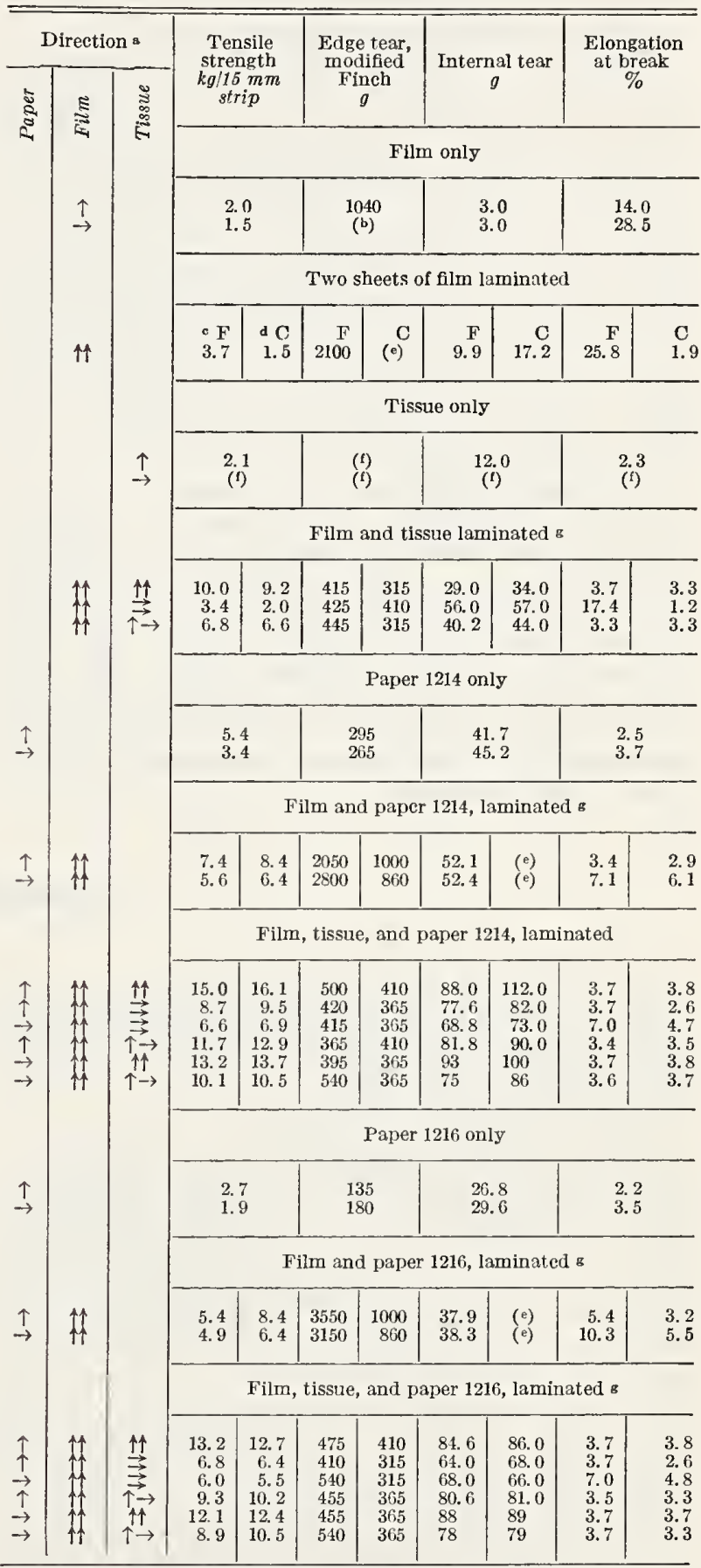

a Arrows indicate machine direction and cross direction of the film, tissue or paper; 1 arrow is shown for each sheet. Vertical arrow indicates machine direction, horizontal arrow indicates cross direction.

b These data were not obtained.

- Laminated on a flatbed press.

d Laminated on a cylindrical type press.

- Insufficient sample.

'Tissue too weak to test.

g The film or the film and tissue extended 2-mm beyond edge of paper. 
The values for edge tear using the modification of the Finch device are not additive. The film has a high edge tear, but when laminated to tissue, the edge tear of the laminate drops to a fraction of that of the film.

The data for $^{\circ}$ internal tear show an interesting interaction in that the sums of the values for tear of the individual sheets add up to considerably less than the values for laminated sheets of film, paper and tissue. As indicated by the data tabulated in table 11 , the amount of interaction depends on whether one uses the tear value of a single sheet of film, multiplied by two, or whether one uses the value of two laminated sheets of film. The laminates prepared on the cylindrical type press show a higher numerical value for internal tear than those prepared on the flatbed press, whereas laminates prepared on the flatbed press show a higher edge tear.

Data on elongation at break follow, in general, an expected pattern. The elongation values of the laminates usually lie between that of the film and of the paper, tissue, or paper and tissue. The values for the laminates usually lie very close to those of the paper or tissue. When the paper or tissue ruptures, this apparently serves as a starting point for a tear in the film. For the same reason, the edge tear of a laminate is much less than that of the film and only slightly higher than that of the paper.
TABLE 11. Internal tear of laminates compared with internal tear of component sheets of the laminates

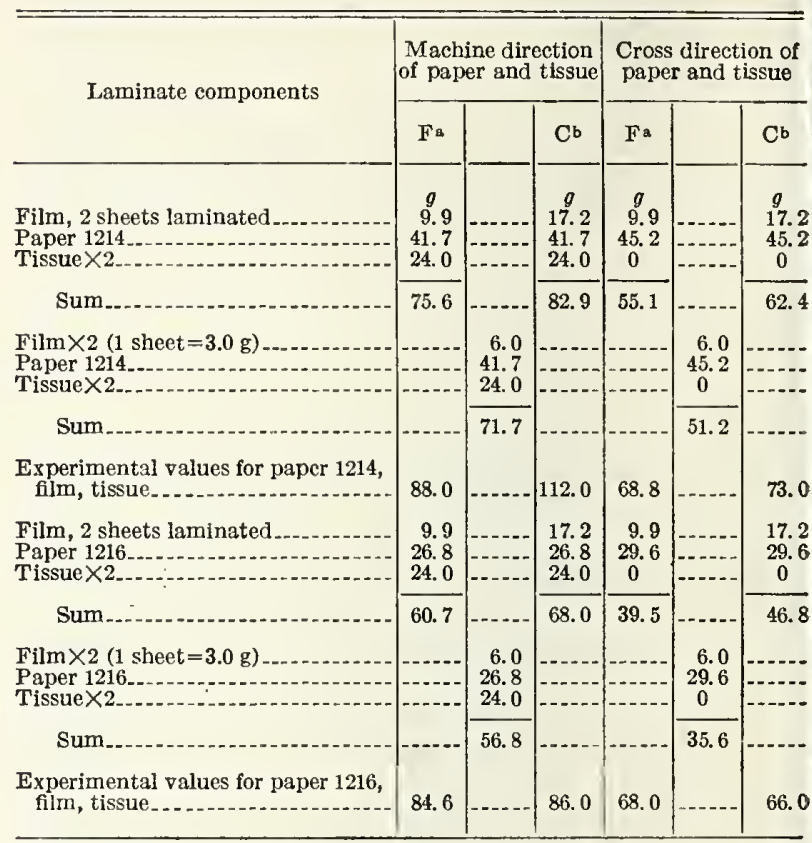

a Laminated on a flatbed press.

b Laminated on a cylindrical type press.

\section{Deacidification}

The term deacidification as used in this paper refers to the Barrow method of neutralizing the acid in paper by means of consecutive washes with saturated solutions of calcium hydroxide and calcium bicarbonate [20].

Two practically neutral papers, containing no sizing, filler, or alum, were selected for this worka cotton rag paper and a soda sulfite wood-pulp paper. Specimens of these papers were treated with $0.02 N$ sulfuric acid, other specimens were treated with 1-percent alum solution, and still others were washed with distilled water. The data from the physical tests of the water-washed specimens were used as controls to compare with data from the physical testing of the acid-and alum-treated papers. Some specimens were deacidified, and some of the specimens were aged at $124^{\circ} \mathrm{C}$ in oxygen for $24 \mathrm{hr}$ with and without prior deacidification. In addition, some of the specimens were laminated and subjected to accelerated aging in order to evaluate the effect of acid in the paper and of deacidification on the film.

The data on the properties of the papers tested in the investigation of deacidification are summarized in table 12 . It is obvious that deacidification prevents the degradation that otherwise occurs during accelerated aging.
Data on the degradation of film laminated to the acid-treated and deacidified papers are plotted in figure 21. One line is drawn through the data from the specimens of film laminated to alum-treated paper and the specimens laminated to acid-treated paper. Also, a single line appears to represent

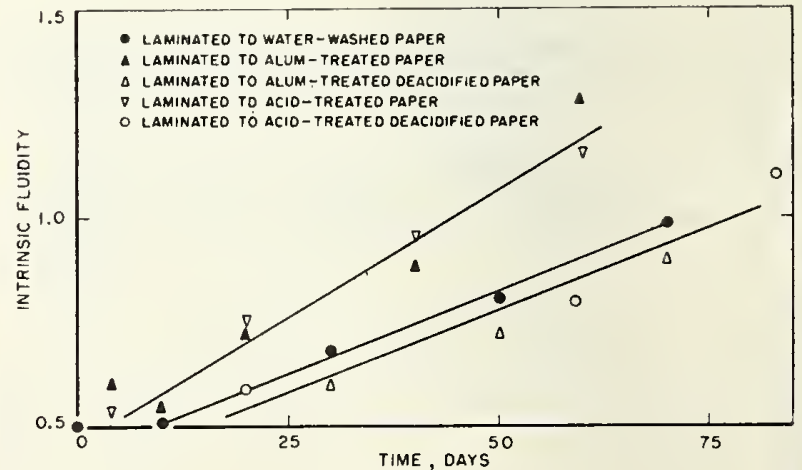

FIGURE 21. Change in intrinsic fluidity with time in moist oxygen at $124^{\circ} \mathrm{C}$ of specimens of commercial cellulose acetate film No. 7 laminated to specimens of paper 732. 
TABLE 12. Effect of deacidification on the accelerated aging of papers

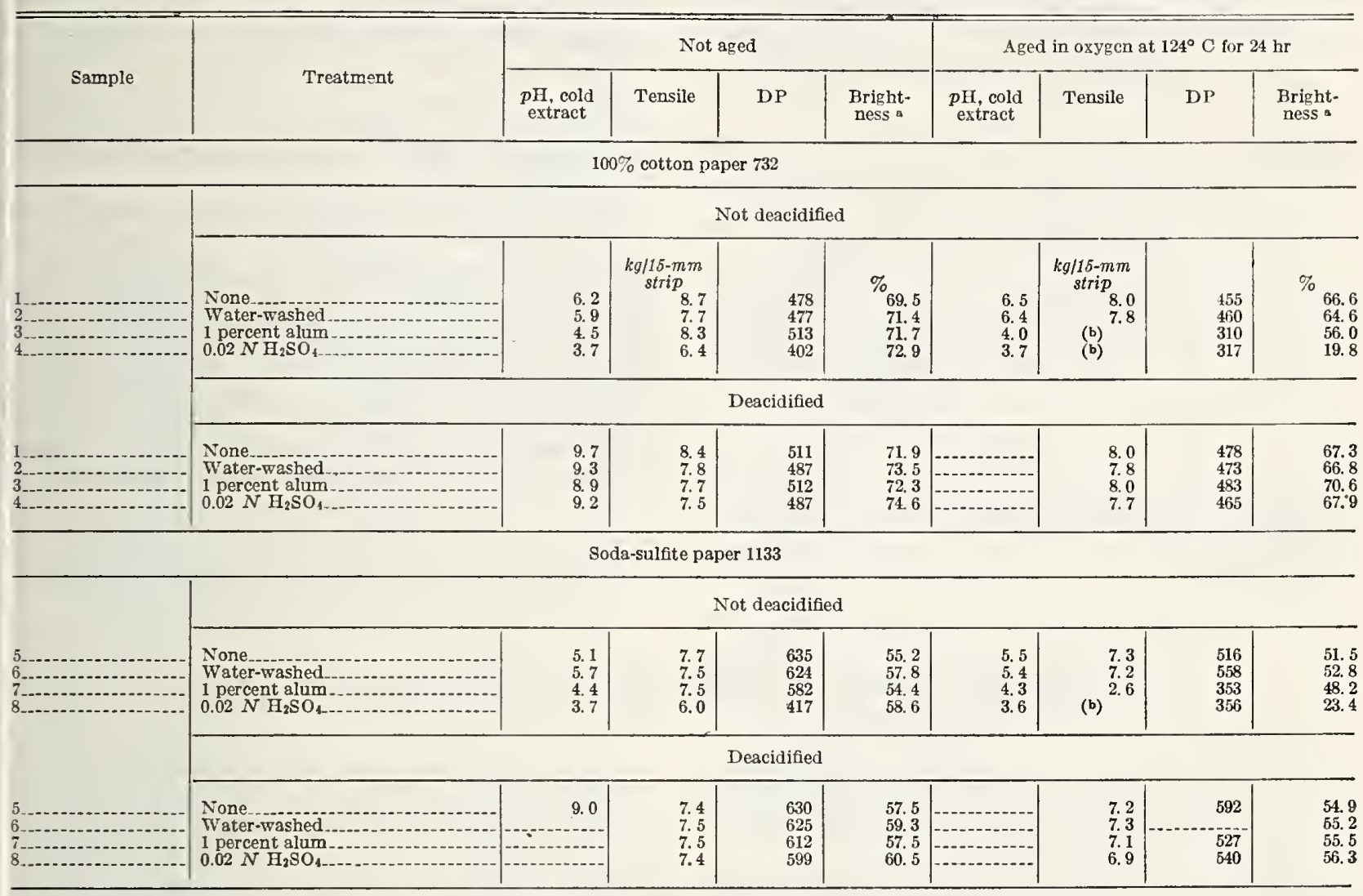

- Reflectance values obtained using the Hunter multipurpose reflectometer with blue filtcr.

b Very weak and brittle.

the data from the films laminated to deacidified papers. It is obvious that acid in the paper accelerates the degradation of the film. Also, deacidification appears to make the film somewhat more stable.

Data on the effect of washing and of deacidification on the physical properties of paper from old books are given in table 13 . Specimens were doacidified in the usual way, and other specimens were treated with water instead of the deacidification solutions. The deacidification process did not cause any significant change in tensile strength or folding endurance.
TABLE 13. Effect of washing and of deacidification on the physical properties of old all-rag papers

\begin{tabular}{|c|c|c|c|c|}
\hline \multirow[b]{2}{*}{ 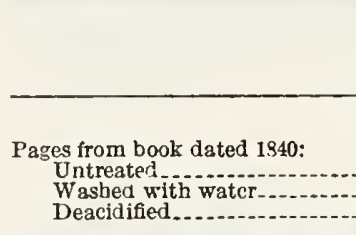 } & \multicolumn{2}{|c|}{$\begin{array}{l}\text { Tenslle strcngth, } \\
\mathrm{kg} / 15-\mathrm{mm} \text { strip }\end{array}$} & \multicolumn{2}{|c|}{$\begin{array}{l}\text { Foldlng endurance, } \\
\text { MIT, 0.5-kg tenslon, } \\
\text { double folds }\end{array}$} \\
\hline & $\begin{array}{r}\text { Mochine } \\
\text { direction } \\
2.9 \\
2.6 \\
2.9\end{array}$ & $\begin{array}{r}\text { Cross } \\
\text { direction. } \\
1.9 \\
1.7 \\
2.0\end{array}$ & $\begin{array}{r}\text { Machine } \\
\text { direction } \\
20 \\
31 \\
31\end{array}$ & $\begin{array}{r}\text { Cross } \\
\text { direction } \\
13 \\
16 \\
18\end{array}$ \\
\hline $\begin{array}{l}\text { Pages from book dated 1869: } \\
\text { Untreated } \\
\text { Washed with watcr. } \\
\text { Deacldlfied......... }\end{array}$ & $\begin{array}{l}3.9 \\
3.7 \\
3.8\end{array}$ & $\begin{array}{l}2.6 \\
2.5 \\
2.4\end{array}$ & $\begin{array}{l}2 \\
4 \\
3\end{array}$ & $\begin{array}{l}2 \\
4 \\
3\end{array}$ \\
\hline
\end{tabular}

\section{Special Laminating Methods}

Although lamination of archival documents with cellulose acetate film is usually accomplished by means of heat and pressure, Kathpalia has described a solvent lamination technique that does not require special equipment [21]. A sandwich, consisting of tissue, film, document, film, and tissue is assembled on a flat surface. Using a nonlinting cloth, acetone is applied to the sandwich in the center and wiped toward the edges. The sandwich is then turned over and the process repeated. Best results are obtained if the laminate is placed in a letter press or hydraulic press for a few hours. Gear [22] has compared some physical properties of laminates prepared by the Kathpalia method with those of laminates prepared using a steamheated flatbed press. These data are reproduced in table 14. It is obvious that the solvent technique compares favorably with the machine method using heat and pressure. The solvent lamination technique should be attractive to an operator who cannot justify the cost of a laminating press. 
Table 14. Physical properties of paper, film, and tissue laminated by solvent a and machine ${ }^{\mathrm{b}}$ techniques

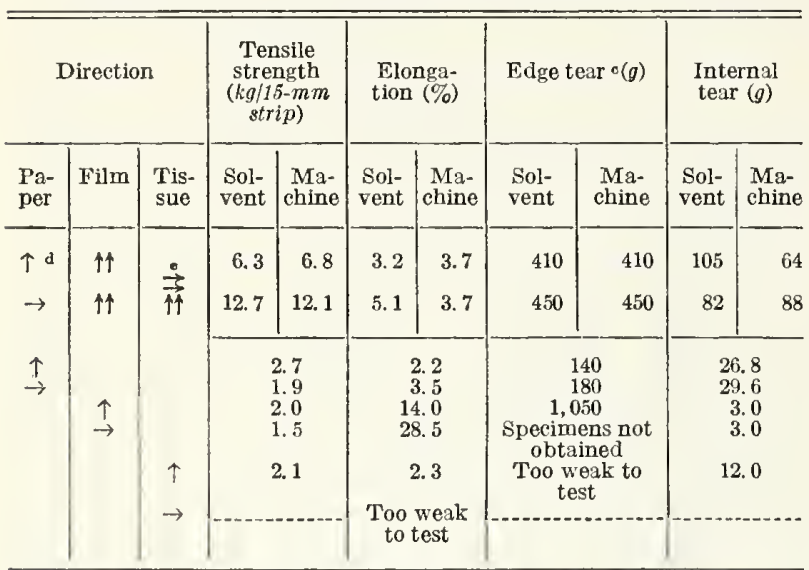

- Kathpalia method of solvent lamination.

b Steam-heated flatbed press; same conditions as described ingection 5 - Modified Finch method.

d Machine direction.

- Cross direction.
Acetone is somewhat toxic, and the maximum allowable concentration in the atmosphere is generally considered to be about 500 volumes of acetone vapor per million volumes of air [23]. Acetone is flammable and mixtures of acetone vapor with air, between 2.5 and 12.8 percent, are explosive [24]. Therefore adequate safety precautions should be maintained.

Another approach which may be useful for special purposes is lamination of a nonwoven fabric, using an adbesive, to one side of the document. Tribolet [25] has suggested this technique for mounting documents for display purposes and to add strength where only limited reinforcement is required. This should add sufficient strength to allow careful handling, and the document would still be available to be "seen and touched" in its original state. The stability of the adbesives and of the nonwoven fabrics is a factor that would bave to be considered in the preservation of documents by this technique.

\section{Preliminary Study of Films Other than Cellulose Acetate}

Polyethylene and polyethylene terephthalate films are probably the only films other than the cellulose ester type which can presently be considered as possible laminating films.

Polyethylene appears promising, especially some of the newer types of polyethylene and a chemically similar polymer, polypropylene. 'This group of polymers merits further study. The loadelongation data in table 4 and figure 22 show some obvious advantages and disadvantages. The yield strength is very low, and the strength at 2- to 3 percent elongation, which is the value that is im-

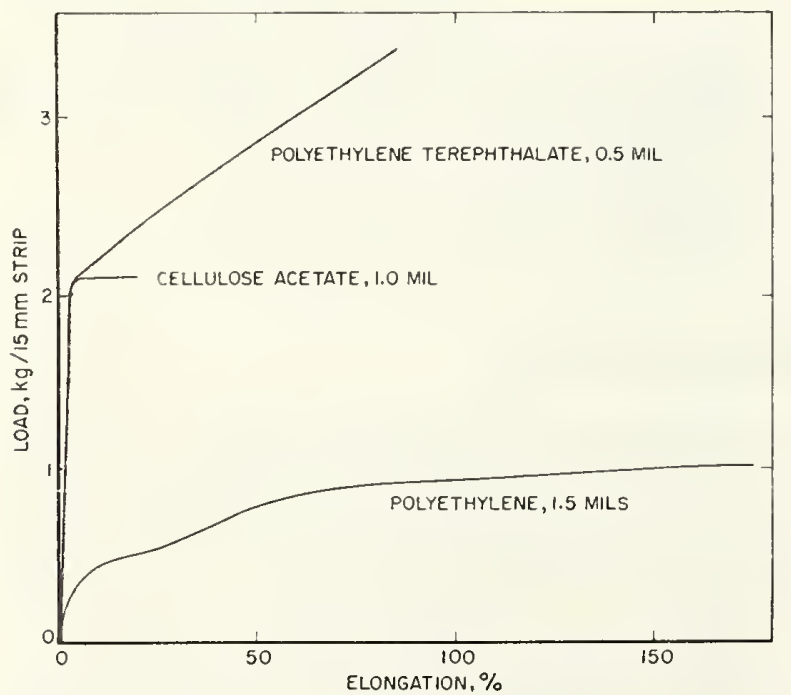

Figure 22. Typical tensile load-elongation curves for cellulose acetate, polyethylene and polyethylene terephthalate. portant in protection of the paper, is still lower. This is probably sufficient for ordinary service, but a much milder impact would be sufficient to damage the laminate than one prepared with cellulose acetate. The edge tear of polyethylene film is comparable to that of cellulose acetate film.

Polyethylene terephthalate has the best physical properties for archival purposes of any film studied. However, the selection of an adhesive with good aging qualities for use with it would require further work.

The load-elongation data in table 4 and figure 22 show that a 0.5 -mil polyethylene terephthalate film is very similar in behavior to 1.0 -mil cellulose acetate film up to the yield point. These two films have similar capacities to protect the body of a document. Polyethylene terephthalate has a much bigher energy to rupture and a higher measured edge tear. Therefore, the edge tear in service should be very satisfactory. It could be used in thinner films to equal the performance of cellulose acetate plus tissue, or in thicker films to substitute for cloth reinforcement.

A problem with films such as polyethylene and polyethylene terephthalate is the difficulty of removal from a document, should this become necessary. Neither film is soluble at room temperature in any known solvent. Although removal is possible, the probability of damage to the document is much greater than with cellulcse acetate. One approach that would make for easier removal is the use of a nonwoven fabric with an adbesive, as discussed in section 7. A nonwoven fabric made from polyethylene tereph thalate fiber would add considerable strength to a document with little increase in thickness, assuming that the proper 
adhesive were available. The open texture of the nonwoven fabric would allow access of a solvent to the adhesive, if removal of the fabric became necessary.
Three NBS directories laminated with polyethylene terephthalate, polyethylene, and cellulose acetate films showed no significant differences in their conditions after about 6 months of use.

\section{Specifications for Archival Laminating Film Formulated from Cellulose Acetate}

\subsection{General}

The basic elements necessary for a performance specification and for a composition specification are given in tables 15 and 16 . It should be noted that the accelerated aging test will require several weeks for completion. Therefore the establishment of a list of acceptable materials under commercial designations, with tests of representative lots at intervals rather than the testing of each procurement lot, may be required.

TABLE 15. Suggested performance requirements for a laminating film formulated from cellulose acetate

\begin{tabular}{|c|c|}
\hline $\begin{array}{l}\text { Tensile strength at break, kilograms per } 15-\mathrm{mm} \text { width, } \\
\text { minimum }\end{array}$ & 1.8 \\
\hline $\begin{array}{l}\text { Tensile strength at sield point, kilograms per } 15-\mathrm{mm} \text { wldth, } \\
\text { minimum. }\end{array}$ & 1.8 \\
\hline Elongation at break, minimum & 15.0 \\
\hline Elongatlon at yleld point....... & $3.5 \pm 0.5$ \\
\hline $\begin{array}{l}\text { Folding endurance, M1T machine at 1-kg tension, double } \\
\text { folds, minimum... }\end{array}$ & 1,000 \\
\hline Thickness.... & $0.88 \pm 10 \%$ \\
\hline $\begin{array}{l}\text { Heat softening temperature: } \\
\text { Moelter-Schweizer } \\
\text { Copper-block method........ }\end{array}$ & $\begin{array}{l}114.5 \pm 2.5 \\
123.5 \pm 2.5\end{array}$ \\
\hline $\begin{array}{l}\text { Accelerated aging for } 40 \text { days in moist oxygen at } 124^{\circ} \mathrm{C} \text { : } \\
\text { Rate of change of intrinsic fluidity with time in days, } \\
\text { maximum } \\
\text { Time to reach an intrinsic fluldity of } 1.0 \text {, minimum.. days. }\end{array}$ & $4^{0.02}$ \\
\hline $\begin{array}{l}\text { Viscoslty of cellulose acetate, centipoises, minimum: } \\
\text { Cast film } \\
\text { Extruded fim }\end{array}$ & $\begin{array}{r}100 \\
60\end{array}$ \\
\hline
\end{tabular}

\subsection{Test Methods}

Tensile strength and elongation shall be determined by ASTM method D 882-56T [26], Method $A$, with a rate of motion of the crosshead of 2 in./min. Special care shall be taken to ensure the first-class condition of the specimen cutter; $a_{0}$ special double-edge film cutter is recommended. The yield point shall be located as indicated in section 3.3 of this publication. A general discussion of stress-strain phenomena is given in references [27] and [28].

Folding endurance shall be determined by method T $423 \mathrm{~m}-50$ of the Technical Association of the Pulp and Paper Industry, using the MIT machine at $1-\mathrm{kg}$ tension. The considerations mentioned above with regard to the specimen cutter shall apply.

Thickness shall be determined by TAPPI method T $411 \mathrm{~m}-44$, using an instrument with an accuracy of 0.0002 in.

\section{TABLE 16. Suggested composition requirements for a cast laminating film formulated from cellulose acetate}

Tolerances in composition requirements should be in accordance with good commercial practlce, and as agreed upon between the buyer and the manufacturer. Tolerances for some items have been suggested by industry representatives and are given here.

Accelcrated aging $\mathrm{a}$ and thickness requirements should be included together with the following composition requirements.

\begin{tabular}{|c|c|}
\hline $\begin{array}{l}\text { Cellulose acetate } \\
\text { Degree of substitution, } 2.4 \pm 0.1 . \\
\text { Viscosity, centipoises, minimum, } 100 \text {. } \\
\text { Bound sulfate, percent, maximum, } 0.05^{\text {h }} \text {. }\end{array}$ & $\begin{array}{l}\text { \%by } \\
\text { weight } \\
\quad 73\end{array}$ \\
\hline $\begin{array}{l}\text { Plasticizer - } \\
\text { Triphenyl phosphate, } 5 \text { percent. } \\
\text { Dimethyl phthalate.d } 20 \text { percent. }\end{array}$ & 25 \\
\hline $\begin{array}{l}\text { Acid acceptor, minimum } \\
\text { Magnesium acetate, epoxy resin acid acceptor, or any other ma- } \\
\text { terial agreed upon between the buyer and the seller. }\end{array}$ & 0.5 \\
\hline $\begin{array}{l}\text { Ultraviolet absorber, minimum } \\
\text { Resorcinol monobenzoate, or any other ultra iolet absorber agreed } \\
\text { upon between the buyer and the seller. The material shall be } \\
\text { one which has been proven satisfactory in actual use, preforably } \\
\text { in weathering applications. }\end{array}$ & 1.0 \\
\hline $\begin{array}{l}\text { Antioxidant, }{ }^{\circ} \text { minimum } \\
\text { Octylohenol }(p-1,1,3,3 \text {-tetramethylbutylphenol), ( }(\text {-cyclohexyl- } \\
\text { phenol), nonylphenol, or any other agreed upon between the } \\
\text { buyer and the seller. }\end{array}$ & 0.5 \\
\hline $\begin{array}{l}\text { fluidity could be } 0.01 \text {, and the minimum time to reach an intrins } \\
1.0 \text { could be } 90 \text { days. } \\
\text { b Very pure cellulose acetates with bound sulfate contents } \\
\text { percent are a vailable, but the price is approximately } 10 \text { cents mor } \\
\text { The acid acceptor is added to neutralize the bound sulfate and pr } \\
\text { dation. } \\
\text { o The triphenyl phosphate could be omitted. In this case the } \\
\text { should contain } 25 \text { percent dimethyl phthalate instead of } 20 \text { per } \\
\text { ever, triphenyl phosphate increases the hardness and durability } \\
\text { d Diethyl phthalate could be substituted for dimethyl phthal } \\
\text { latter is the better choce. } \\
\text { o These antioxidants have been recommended by a manufact } \\
\text { lose acetate film. }\end{array}$ & $\begin{array}{l}\text { osition } \\
\text { itrinsic } \\
\text { dity of } \\
\text { d } 0.002 \\
\text { pound. } \\
\text { degra- } \\
\text { dation } \\
\text { How- } \\
\text { film. } \\
\text { ut the } \\
\text { f collu- }\end{array}$ \\
\hline
\end{tabular}

Heat softening temperature shall be determined by the method of Moelter and Schweizer [19], or by placing the specimen on a polished copper block and heating at the rate of $15^{\circ} \mathrm{C} / \mathrm{min}$. until the specimen becomes limp [18].

Bound sulfate content shall be determined by the method of Malm and Tanghe [29].

Intrinsic fluidity shall be determined as follows: Weigh the cellulose acetate with an accuracy of $\pm 0.2 \mathrm{mg}$ making allowance for the plasticizer. Dissolve the cellulose acetate in enough of the solvent (9 parts of methylene chloride and 1 part of methyl alcohol by weight), precisely measured, to give a solution about one percent in cellulose acetate by weight. Transfer the solution quantitatively to an Ubbelohde suspended-level viscometer and measure the time of flow at $20 \pm 0.1^{\circ} \mathrm{C}$. Dilute the cellulose acetate solution with viscosity solvent, precisely measured, to about $3 / 2$ and $1 / 4$ percent cellulose acetate, measuring the time of 
flow after each dilution. Finally, measure the time of flow of pure solvent and calculate the specific viscosity for each dilution from the equation:

$$
\frac{\text { Viscosity (solution)-viscosity (solvent) }}{\text { Viscosity (solvent) }}
$$

$$
\text { Plot the logarithm of } \frac{\text { specific viscosity }}{\text { concentration }} \text { against }
$$

concentration and extrapolate to zero cencentration to obtain the intrinsic viscosity. The intrinsic fluidity is the reciprocal of intrinsic viscosity.

Any viscometer with a range of 0.5 to $2.5 \mathrm{cp}$ should be satisfactory. An Ubbelohde suspendedlevel is preferable, with a large reservoir at the bottom of the viscometer, making it possible to dilute the solution in the viscometer. The instrument may be calibrated using standard oils obtained from NBS. Directions for calibrating viscometers are given in reference [30].

$V i s c o s i t y$ of cellulose acetate. Enough film, making allowance for the plasticizer, shall be taken to give $6 \pm 0.01 \mathrm{~g}$ of cellulose acetate. This shall be dissolved in $100 \pm 0.1 \mathrm{ml}$ of a mixture of $95 \pm 0.1 \mathrm{~g}$ of acetone and $5 \pm 0.01 \mathrm{~g}$ of water. The viscosity shall be measured at $23^{\circ} \mathrm{C}$ by the ASTM ball-drop method, D 1343 [31].

Degree of substitution shall be determined by ASTM method D 871 [32]. This method determines the acetic acid or acetyl content, from which the degree of substitution may be calculated.

Plasticizer content shall be determined by the method of Whitnack and Gantz [13]. A value for total plasticizer is sufficient.

Accelerated aging. The film shall be aged at $124^{\circ} \pm 0.2^{\circ} \mathrm{C}$ in flowing oxygen $(50 \pm 5 \mathrm{ml} / \mathrm{min}$.) moistened with water vapor at $30^{\circ} \mathrm{C}$. Several acceptable ways of doing this are described bere.

An oil bath is satisfactory for maintaining the specimens at $124^{\circ} \mathrm{C}$. Although somewhat expensive, a silicone oil, that can be used up to about $180^{\circ} \mathrm{C}$, is very stable and gives excellent results. Other oils could be used, but none is as satisfactory as the silicone fluid. Either a stainless steel or glass container for the oil is satisfactory. A convenient arrangement is to fit a stainless steel beaker into an electrical heating mantle in an aluminum housing and supply enough electrical energy from a variable transformer to the mantle to maintain the oil a few degrees below $125^{\circ} \mathrm{C}$. A small electrical tape heater between the mantle and the beaker (or a small immersion heater in the oil) can be used to supply heat in termittently from a relay to maintain the bath at about $125^{\circ} \mathrm{C}$ in order to keep the temperature of the specimens at $124^{\circ} \mathrm{C} \pm 0.2$. It is desirable to measure the temperature inside the reaction vessel with a thermocouple. A good quality mercury regulator is necessary to control the current to the small tape heater or immersion heater. As this regu- lator can carry only a very small current, it is connected to a relay through which current is supplied to the tape heater.

The temperature of the oil bath should be measured with a thermometer that can be read with an accuracy of $0.1^{\circ} \mathrm{C}$. A small continuous duty stirrer is necessary to maintain a uniform temperature in the bath.

A reflux type of constant temperature apparatus, using a liquid that boils at the desired temperature, may be used. Although not as accurate or as flexible as an oil bath, the investment in time and money for setting up the equipment is relatively small.

Many types of reaction vessels will serve the purpose. One type of reaction vessel is made by sealing a coarse fritted-glass funnel to a standard taper joint. The fritted glass serves as a platform for the specimens, which are loosely rolled up in glass tubes. The rate of flow of oxygen is not critical unless an antioxidant is present, in which case a high rate of flow causes the antioxidant to disappear from the film at a high rate. Therefore, in order to compare the degradation rates of films that may contain antioxidants, it is necessary to use comparable rates of oxygen flow, and special reaction vessels holding only one specimen.

The oxygen flow may be regulated by a twostage reducing valve for one reaction vessel, but for several reaction vessels it is necessary to provide a copper or brass pipe manifold with good quality needle valves. By keeping a definite pressure on the manifold, e.g., $10 \mathrm{lb}$, the flow in each needle valve can be adjusted without disturbing the adjustment of any other valve. The flow rate may be measured with sufficient accuracy by displacement of water in a graduated cylinder.

In order to obtain a value for rate of change of intrinsic fluidity with time, intrinsic fluidity is plotted as the ordinate and time in days is plotted as the abscissa. The rate of degradation is the slope of this plot. Some judgment must be used in drawing a line through the experimental points, as there are many cases where a single straight line cannot be drawn. Sometimes there is an induction period of several days during which little or no degradation occurs. This is characteristic of many formulations, and a film containing an antioxidant exhibits this behavior to a marked degree. Therefore, one straight line would represent the induction period and have a low slope or a slope of 0 . Another straight line would be drawn through the points obtained beyond the induction period.

\subsection{Improvements in Specifications}

As indicated above, it is desirable that the film contain an acid acceptor, e.g., in the form of calcium or magnesium salts to neutralize the bound sulfate residue in the cellulose acetate. Most of the bound sulfate is removed after acetylation, but it is not practicable to remove the last traces. The determination of the amount of acid acceptor 
should be a simple matter of water extraction and electrometric titration, but a method has not been developed.

The determination of the amount of ultraviolet absorbers and antioxidants has received little attention in the technical literature, and the establishment of suitable methods would require considerable research. Therefore, the inclusion of such stabilizers as a part of a specification for an archival film can only be an expression of desire on the part of the purchaser, as procurement lots could not be analyzed with confidence for compliance with specifications.

Presumably, an ultraviolet absorber would disappear from a film after soreral years. Assuming that a laminated document would receive the most use during the first few years after lamination, the absorber should minimize degradation due to light during this period. However, as it probably would not be present for the full life of the film, it is important that the film have good stability irrespective of the presence of stabilizers.

It has been shown in this investigation that antioxidants prevent oxidative degradation, at least for a time, of films which would otherwise be very unstable. The extent of this protection depends on how long antioxidants remain in the film. Not enough information is arailable to be able to say whether a film containing a stabilizer and a plasticizer that contributes to oxidative instability could be detected with certainty by means of aging in flowing oxygen at $124^{\circ} \mathrm{C}$.

The composition specification calls for two plasticizers, triphenyl phosphate and dimethyl phthalate. The dimethyl phthalate is an active solvent plasticizer and is necessary for lowering the softening point of the film. Diethyl phthalate could be substituted for dimethyl phthalate. It is not quite as effective in lowering the softening point, but it is not quite as rolatile, and dimensional stability of films containing it is better than those containing dimethyl phthalate. The choice is not particularly critical.

Triphenyl phosphate has been included because films containing it show good aging properties in oxygen at $124^{\circ} \mathrm{C}$. If a film contains a good antioxidant, it is probable that the triphenyl phosphate would not be necessary. On the other hand, tri- phenyl phosphate does enhance the physical properties of the film.

Experience in the procurement of archival film using these suggested specifications should result in improvement in the specifications. One possibility would be to combine the best parts, as shown by experience, of the performance and the composition specifications into one specification. It is suggested that the specifications always be kept as flexible as possible in order to take advantage of new developments.

\subsection{Problems in Procurement}

A cellulose acetate film may be made either by casting or by extruding. In making a cast film, the ingredients are dissolved in an appropriate solvent and the film is cast by causing the solution to flow onto a large wheel or moving belt from which the solvent is evaporated. This is a continuous process. Although the principle is very simple, and films can be cast in the laboratory using inexpensive equipment, the continuous largescale casting of commercial films is not easily adaptable to formulation changes. The manufacture of special formulations by casting is not attractive to film producers unless the tonnage of film required is large enough to warrant the high cost of starting and stopping the complicated system associated with film casting.

Manufacturers probably would be willing to make an extruded film in a special formulation, as extrusion is a batch operation instead of a continuous operation. However, the ingredients must be mixed hot in a milling machine, and this causes some degradation. An extruded film is seldom as perfect in appearance as a cast film. This is considered to be of negligible importance, however, as these imperfections are not likely to be noticeable after lamination. An extruded film probably would be a little cheaper than a cast film.

The authors acknowledge with thanks the assistance and cooperation of the various sponsors throughout this project. The able assistance of Mr. Wilbur Poole, who was on detail from National Archives for more than a year, is gratefully acknowledged.

\section{References}

[1] B. W. Scribner, Protection of documents with cellulose acetate sheeting, NBS Misc. Publ: M168, 1941.

[2] W. K. Wilson and B. W. Forshee, SPE Journal 15, 146 (Feb. 1959).

[3] G. C. DeCroes and J. W. Tamblyn, Protection of cellulose esters against breakdown by heat and light, Modern Plastícs 29, 127 (April 1952).

[4] ASTM D 1203-55, Volatile loss from plastic materials, ASTM Book of Standards, pt 9, p. 476 (1958).
[5] ASTM D 786-49, Standard specifications for cellulose acetate plastic sheets, ASTM Book of Standards, pt 9, p. 136 (1958).

[6] ASTM D 756-56, Resistance of plastics to accelerated service conditions, ASTM Book of Standards, pt 9, p. 441 (1958).

[7] ASTM E 95-58T, Tentative specifications for celltype oven with controlled rates of ventilation, ÁSTM Book of Standards, pt 9, p. 1867 (1958). 
[8] A. K. Doolittle, The technology of solvents and plasticizers, Chapt. 15 (John Wiley \& Sons, Inc., New York, N.Y., 1954).

[9] H. M. Quackenbos, Jr., Plasticizers in vinyl chloride resins, Ind. Eng. Chem. 46, 1335 (1954).

[10] M. C. Reed, H. F. Klemm, and E. F. Schulz, Plasticizers in vinyl chloride resins, Ind. Eng. Chem. 46, 1344 (1954).

[11] L. H. Wartman and W. J. Frissell, Plasticizer problems in vinyl resin studies, Plastics Technol. 2, 583 (Sept. 1956).

[12] W. J. Frissell, Volatility of vinyl plasticizers, Ind. Eng. Chem. 48, 1096 (1956).

[13] G. C. Whitnack and E. Gantz, Extraction and determination of plasticizers from cellulose acetate plastics, Anal. Chem. 24, 1060 (1952).

14] J. H. Flynn, Rapid determination of the order of chemical reactions by time-ratio tables (in preparation).

[15] Hercules Powder Co., Cellulose acetate properties and uses, 1954 edition.

[16] ASTM D 903-49 Peel or stripping strength of adhesives, ASTM Book of Standards, pt 7, p. 1182 (1955).

[17] T. J. Carter and J. R. Kanagy, A flex tension test for leather, J. Am. Leather Chemists' Assoc. 49, 23 (1954).

[18] Celanese Corp. of America, Celanesc acetate sheeting and film.

[19] G. M. Moelter and E. Schweizer, Heat softening of cellulose acetate, Ind. Eng. Chem. 41, 684 (1949).

[20] W. J. Barrow, Manuscripts and Documents-their deterioration and restoration (University of Virginia Press, Charlottesville, Va., 1955); Restoration methods, Ám. Archivist 6, 151 (1943).
[21] Y. Kathpalia, Hand lamination with cellulose acetate, Am. Archivist 21, 271, No. 3 (July 1958).

[22] J. L. Gear, Comments on Mr. Kathpalia's article, Am. Archivist 21, 275, No. 3 (Juiy 1958).

[23] The Merck Index, p. 8 (Merck and Co., Inc., Rahway, N.J., 1952).

[24] M. B. Jacobs, The analytical chemistry of industrial poisons, hazards and solvents, p. 618 (Interscience Publishers, Inc., New York, N.Y., 1941).

[25] H. W. Tribolet, private communication.

[26] ASTM D 882-56, Methods of test for tensile properties of thin plastic sheets and films, ASTM Book of Standards, pt 9, p. 335 (1958).

[27] A. X. Schmidt and C. A. Marlies, Principles of high polymer theory and practice (McGraw-Hill Book Co., Inc., New York, N.Y., 1948).

[28] ASTM D 638-58T, Test for tensile properties of plastics ASTM Book of Standards, pt 9, p. 329 (1958).

[29] C. J. Malm and L. J. Tanghe, Determination of small amounts of combined sulfur, Ind. Eng. Chem., Anal. Ed. 14, 940 (1942).

[30] M. R. Cannon and M. R. Fenske, Viscosity measurement, Ind. Eng. Chem., Anal. Ed. 10, 297 (1938).

[31] ASTM D 1343-56, Viscosity of cellulose derivatives by ball drop method, ASTM Book of Standards, pt 4 , p. 801 (1955).

[32] ASTM D. 871-56, Methods of testing cellulose acetate, ASTM Book of Standards, pt 4, p. 776 (1955).

Washington, D.C., July 9, 1959. 


\section{THE NATIONAL BUREAU OF STANDARDS}

The scope of activities of the National Bureau or Standards at its major laburatories in Washington, D.C., and Boulder, Colorado, is suggested in the following listing of the divisions and sections engaged in technical work. In general, each section carries out specialized research, development, and engineering in the field indicated by its title. A brief description of the activities, and of the resultant publications, appears on the inside of the front cover.

\section{WASHINGTON, D.C.}

Electricity and Electronics. Resistance and Reactance. Electron Devices. Electrical Instruments. Magnetic Measurements. Dielectrics. Engineering Electronics. Electronic Instrumentation. Electrochemistry.

Optics and Metrology. Photometry and Colorimetry. Optical Instruments. Photographic Technology. Length. Engineering Metrology.

Heat. Temperature Physics. Thermodynamics. Cryogenic Physics. Rheology. Molecular Kinetics. Free Radicals Research.

Atomic and Radiation Physics. Spectroscopy. Radiometry. Mass Spectrometry. Solid State Physics. Electron Physics. Atomic Physics. Neutron Physics. Radiation Theory. Radioactivity. X-ray. High Energy Radiation. Nucleonic Instrumentation. Radiological Equipment.

Chemistry. Organic Coatings. Surface Chemistry. Organic Chemistry. Analytical Chemistry. Inorganic Chemistry. Electrodeposition. Molecular Structure and Properties of Gases. Physical Chemistry. Thermochemistry. Spectrochemistry. Pure Substances.

Mechanics. Sound. Mechanical Instruments. Fluid Mechanics. Engineering Mechanics. Mass and Scale. Capacity, Density, and Fluid Meters. Combustion Controls.

Organic and Fibrous Materials. Rubher, Textiles. Paper. Leather. Testing and Specifications. Polymer Structure. Plastics. Dental Research.

Metallurgy. Thermal Metallurgy. Chemical Metallurgy. Mechanical Metallurgy. Corrosion. Metal Physics. Mineral Products. Engineering Ceramics. Glass. Refractories. Enameled Metals. Constitution and Microstructure.

Building Technology. Structural Engineering. Fire Protection. Air Conditioning, Heating, and Refrigeration. Floor, Roof, and Wall Coverings. Codes and Safety Standards. Heat Transfer. Concreting Materials.

Applied Mathematics. Numerical Analysis. Computation. Statistical Engineering. Mathematical Physics.

Data Processing Systems. SEAC Engineering Group. Components and Techniques. Digital Circuitry. Digital Systems. Analog Systems. Applications Engineering.

- Office of Basic Instrumentation.

- Office of Weights and Measures

\section{BOULDER, COLORADO}

Cryogenic Engineering. Cryogenic Equipment. Cryogenic Processes. Properties of Materials. Gas Liquefaction.

Radio Propagation Physics. Upper Atmosphere Research. Ionosphere Research. Regular Prediction Services. Sun-Earth Relationships. VIIF Research. Radio Warning Services. Airglow and Aurora. Radio Astronomy and Arctic Propagation.

Radio Propagation Engineering. Data Reduction Instrumentation. Radio Noise. Tropospheric Measurements. Tropospheric Analysis. Propogation-Terrain Effects. Radio Meteorology. Lower Atmosphere Physics.

Radio Standards. High Frequency Electrical Standards. Radio Broadcast Service. Radio and Microwave Materials. Electronic Calibration Center. Microwave Circuit Standards.

Radio Communication and Systems. Low Frequency and Very Low Frequency Research. High Frequency and Very High Frequency Research. Modulation Systems. Antenna Research. Navigation Systems. Systems Analysis. Field Operations. 
